\title{
Short-Term Effects of Biogas Digestates and Pig Slurry Application on Soil Microbial Activity
}

\author{
J. Abubaker, ${ }^{1,2}$ K. Risberg, ${ }^{1}$ E. Jönsson, ${ }^{1}$ A. S. Dahlin, ${ }^{3}$ H. Cederlund, ${ }^{1}$ and M. Pell ${ }^{1}$ \\ ${ }^{1}$ Department of Microbiology, Swedish University of Agricultural Sciences (SLU), P.O. Box 7025, 75007 Uppsala, Sweden \\ ${ }^{2}$ Department of Soil and Water, Faculty of Agriculture, Sabha University, P.O. Box 19332, Sabha, Libya \\ ${ }^{3}$ Department of Soil and Environment, Swedish University of Agricultural Sciences (SLU), P.O. Box 7014, 75007 Uppsala, Sweden
}

Correspondence should be addressed to M. Pell; mikael.pell@slu.se

Received 9 October 2014; Accepted 27 November 2014

Academic Editor: Rafael Clemente

Copyright (C) 2015 J. Abubaker et al. This is an open access article distributed under the Creative Commons Attribution License, which permits unrestricted use, distribution, and reproduction in any medium, provided the original work is properly cited.

\begin{abstract}
The effect of four biogas digestates (BD-A, BD-B, BD-C, and BD-D) and pig slurry (PS) on soil microbial functions was assessed at application rates corresponding to $0-1120 \mathrm{~kg} \mathrm{NH}_{4}^{+}-\mathrm{N} \mathrm{ha}^{-1}$. At dose corresponding to $140 \mathrm{~kg} \mathrm{NH}_{4}^{+}-\mathrm{N} \mathrm{ha}^{-1}, 30.9-32.5 \%$ of the carbon applied in BD-A, BD-C, and PS was utilized during 12 days, while for BD-B and BD-D corresponding utilization was 19.0 and $16.9 \%$, respectively. All BDs resulted in net nitrogen assimilation at low rates $\left(17.5-140 \mathrm{~kg} \mathrm{NH}_{4}{ }^{+}-\mathrm{N} \mathrm{ha}^{-1}\right)$ but net mineralization dominated at higher rates. PS resulted in net mineralization at all application rates. All residues inhibited potential ammonium oxidation (PAO), with $\mathrm{EC}_{50}$-values ranging between 45 and $302 \mathrm{~kg} \mathrm{NH}_{4}{ }^{+}-\mathrm{N} \mathrm{ha}^{-1}$. Low rates of BDs appeared to weakly stimulate potential denitrification activity (PDA), while higher rates resulted in logarithmic decrease. The $\mathrm{EC}_{50}$-values for PDA were between 238 and $347 \mathrm{~kg} \mathrm{NH}_{4}{ }^{+}-\mathrm{N} \mathrm{ha}^{-1}$. No inhibition of PDA was observed after amendment with PS. In conclusion, biogas digestates inhibited ammonia oxidation and denitrification, which could be an early warning of potential hazardous substances in the digestates. However, this effect can also be regarded as positive, since it may reduce nitrogen losses.
\end{abstract}

\section{Introduction}

In recent years, the production of biogas from different organic substrates has increased dramatically [1], resulting in an increase in the amount of biogas digestates generated [2]. The potential of biogas digestates as fertilizers has gained great attention due to their beneficial plant nutrient profiles and content of organic material [3] and, hence, their potential to reduce the use of mineral fertilizers. However, the chemical properties of the biogas digestates vary, due to the wide range of raw materials used as substrates in the biogas process. Common substrates are animal manure, slaughterhouse waste, source-separated municipal household-waste, restaurant waste, waste from the food industry, sludge from wastewater treatment, crop residues, and residues from the bioenergy sector $[4,5]$. Therefore, the biogas digestates generated may also contain potentially toxic substances, for example, heavy metals [6] and organic toxicants $[7,8]$, which might affect the soil ecosystem negatively. Due to insufficient confidence in its quality and safety as well as unfamiliarity with the product, the use of these residues is still limited. In order to close the knowledge gaps, biogas digestates should be evaluated for their short- and long-term effects before largescale application to arable land.

Short-term soil effects could be very different from effects in the long run. The short-term effect reflects the situation at the time of fertilization, when high amount of fertilizer is added in relation to the short-term need by the soil and plant system. This imbalanced input is common practice in agriculture but induces stress to the microbial ecosystem and may affect critical soil functions, such as those within the carbon and nitrogen cycle. Soil microbial processes in general have been shown to be sensitive indicators of short- and long-term changes of soil properties following application of organic residues $[9,10]$. Microorganisms are in direct contact with roots, soil particles, and chemicals, and their production of enzymes responds quickly to changes in the soil environment [11]. Hence, the soil microbial community can be used as a "test-organism" in order to detect inhibitory or toxic compounds in an organic fertilizer that could 
otherwise be very expensive or even impossible to analyze. If negative effects are detected this could motivate a more thorough chemical investigation.

Several microbial soil tests related to carbon cycling have been used to assess and monitor soil quality [12]. For instance, soil respiration provides information on the heterotrophic activity of the microbial biomass [13], and estimates of total soil microbial biomass are commonly used as indicators of soil quality [14]. Tests of microbial functions related to the nitrogen cycle may be particularly useful when assessing soil microbial health and determining plant nitrogen availability [15]. All main microbial processes in the nitrogen cycle, mineralization, immobilization or assimilation, nitrification, denitrification, and nitrogen fixation, have been used for studying treatment effects on soil $[9,16]$. Denitrification and nitrification are sensitive to disturbances and hence these processes are ideal for detecting the presence of contaminants such as heavy metals, pesticides, and organic toxicants [9, 17]. In general, nitrification, that is, ammonia oxidation and nitrite oxidation, is performed by only a small number of specialist species within bacteria but also within Archaea, which makes monitoring nitrification a suitable tool for predicting toxicity [18]. By contrast, nitrogen mineralization is performed by a multitude of species with the ability to replace each other if any group is negatively affected and may be more suitable for detecting general impacts and changes in soil fertility and nitrogen availability [19].

The overall aim of the present study was to evaluate the suitability of using biogas digestates as fertilizers in arable cropping. In dose-response tests we studied the short-term effect on soil microbial respiration, nitrogen mineralization capacity, ammonium oxidation, and denitrification potential in order to detect any negative effects on these critical soil functions. The effects induced by the digestates were compared to those induced by pig slurry, a well-known fertilizer used in agriculture.

\section{Material and Methods}

2.1. Soil Sampling and Characteristics. Clay soil was collected from the top 0-20 cm layer of an arable field located in central Sweden (N 59 $36.985^{\prime}$, E $16^{\circ} 39.674^{\prime}$ (WGS84; lat., lon.). The soil is classified as an Eutric Cambisol (FAO 1998) and has since 1998 annually been fertilized with $100 \mathrm{~kg} \mathrm{~N}\left(50 \% \mathrm{NH}_{4}\right.$ $\mathrm{N}$ and $50 \% \mathrm{NO}_{3}-\mathrm{N}$ ). No farmyard manure has been applied since 1975. From 1998 a simple crop rotation has been applied with spring barley and oats grown in alternate years; the crop residue is removed as straw. After sampling, the soil was briefly stored at $+2^{\circ} \mathrm{C}$ before it was sieved $(\varnothing<4 \mathrm{~mm})$, thoroughly mixed, and then portioned into polyethylene bags and stored at $-20^{\circ} \mathrm{C}$ until use [20]. Total soil carbon (Tot-C), total nitrogen (Tot-N), and total sulphur (Tot-S) were determined after combustion at $1250^{\circ} \mathrm{C}$ with a carbon, nitrogen, and sulphur analyzer (CNS-2000, LECO Equipment Corp., St. Joseph, MI, USA). Tot-C was corrected for carbonate to give organic carbon (Org-C). Available phosphorus (P-AL) and potassium (K-AL) were extracted with the ammonium lactate method (AL) and analyzed as described by Egnér et al. [21]. The $\mathrm{pH}$ was determined in $0.01 \mathrm{M} \mathrm{CaCl}_{2}$ with
TABLE 1: Chemical, physical, and microbiological characteristics of the soil used in the experiment [10].

\begin{tabular}{|c|c|}
\hline Parameter & Value \\
\hline \multicolumn{2}{|l|}{ Chemical analyses } \\
\hline $\mathrm{pH}$ & 5.6 \\
\hline Org-C (\%) & 1.3 \\
\hline Tot-C (\%) & 1.3 \\
\hline Tot-N (\%) & 0.1 \\
\hline Tot-P (mg kg $\left.{ }^{-1} \mathrm{ds}\right)$ & 700 \\
\hline Tot-S (mg kg $\left.{ }^{-1} \mathrm{ds}\right)$ & 200 \\
\hline P AL (mg kg $\left.{ }^{-1} \mathrm{ds}\right)$ & 48 \\
\hline $\mathrm{K} \mathrm{AL}\left(\mathrm{mg} \mathrm{kg}^{-1} \mathrm{ds}\right)$ & 185 \\
\hline $\mathrm{Cu}\left(\mathrm{mg} \mathrm{kg}^{-1} \mathrm{ds}\right)$ & 26 \\
\hline $\mathrm{Zn}\left(\mathrm{mg} \mathrm{kg}^{-1} \mathrm{ds}\right)$ & 91 \\
\hline $\mathrm{Cd}\left(\mathrm{mg} \mathrm{kg}^{-1} \mathrm{ds}\right)$ & 0.3 \\
\hline $\mathrm{Ni}\left(\mathrm{mg} \mathrm{kg}^{-1} \mathrm{ds}\right)$ & 24 \\
\hline $\mathrm{Pb}\left(\mathrm{mg} \mathrm{kg}^{-1} \mathrm{ds}\right)$ & 20 \\
\hline $\mathrm{Cr}\left(\mathrm{mg} \mathrm{kg}^{-1} \mathrm{ds}\right)$ & 36 \\
\hline \multicolumn{2}{|l|}{ Physical analyses } \\
\hline $\mathrm{DM}(\%)$ & 85.3 \\
\hline Sand (\%) & $14-20$ \\
\hline Silt (\%) & $36-44$ \\
\hline Clay (\%) & $37-49$ \\
\hline WHC $\left(\mathrm{gg}^{-1} \mathrm{ds}\right)$ & 0.51 \\
\hline \multicolumn{2}{|l|}{ Microbial analyses } \\
\hline $\operatorname{NMC}\left(\mu \mathrm{g} \mathrm{N} \mathrm{g}^{-1} \mathrm{ds} 10 \mathrm{~d}^{-1}\right)$ & 21.2 \\
\hline $\mathrm{PAO}\left(\mathrm{ng} \mathrm{NO}_{2}-\mathrm{Ng} \mathrm{g}^{-1} \mathrm{ds} \mathrm{min}^{-1}\right)$ & 4.8 \\
\hline $\mathrm{PDA}\left(\right.$ ng $\mathrm{N}_{2} \mathrm{O}-\mathrm{N} \mathrm{g}^{-1} \mathrm{ds} \min ^{-1}$ ) & 7.8 \\
\hline B-resp $\left(\mu \mathrm{g} \mathrm{CO}_{2} \mathrm{~g}^{-1} \mathrm{ds} \mathrm{h}^{-1}\right)$ & 0.78 \\
\hline $\operatorname{SIR}\left(\mu \mathrm{g} \mathrm{CO}_{2}-\mathrm{Cg}^{-1} \mathrm{ds} \mathrm{h}^{-1}\right)$ & 13.5 \\
\hline
\end{tabular}

the vol/vol ratio $1: 2\left(\mathrm{pH}_{\mathrm{CaCl} 2}\right)$. Pseudo-total phosphorus (Tot-P), cadmium $(\mathrm{Cd})$, chromium $(\mathrm{Cr})$, copper $(\mathrm{Cu})$, nickel $(\mathrm{Ni})$, lead $(\mathrm{Pb})$, and zinc $(\mathrm{Zn})$ were analyzed by ICPMS (Perkin-Elmer ICP Optima 3000, Waltham, MA, USA) according to SS 028311 [22]. Dry matter (DM) was assessed by the method described by McLaren and Cameron [23]. The particle size distribution was determined by the pipette method according to Jung [24]. The analyses of biological properties of the soil are described below (see Section 2.4, Microbiological Assays). The chemical, physical, and biological characteristics of the soil are presented in Table 1.

2.2. Organic Residues. Biogas digestates were collected from four large-scale biogas plants (BD-A, BD-B, BD-C, and BD$D)$ in Sweden. The digestates were chosen to represent both mesophilic and thermophilic processes fed with a wide range of organic residues from municipality and agriculture. All digestates fulfilled the SPCR 120 certification rules for a safe fertilizing agent (http://www.avfallsverige.se/in-english/; 21/11/14). These certification rules are based on documents such as the European Union health rules regarding animal by-products and derived products not intended for consumption (EC number 1069/2009; http://eur-lex.europa .eu/; 25/11/14). Furthermore, all values for metals, except for 
TABLE 2: Operating parameters of the biogas plant reactors (i.e., temperature, retention time, and substrate) from which the four biogas digestates (BD-A, BD-B, BD-C, and BD-D) were obtained.

\begin{tabular}{|c|c|c|c|c|c|}
\hline Operation parameters & Type & BD-A & BD-B & $\mathrm{BD}-\mathrm{C}$ & BD-D \\
\hline Temperature & & Mesophilic $^{1}$ & Thermophilic $^{2}$ & Thermophilic $^{1}$ & Mesophilic $^{2}$ \\
\hline Retention time (days) & & $40-50$ & $40-50$ & $40-50$ & 20 \\
\hline \multirow{7}{*}{ Substrate type ${ }^{3}$ I-VII (\%) } & I & 40 & - & 33 & - \\
\hline & II & 60 & - & 24 & 66 \\
\hline & III & - & - & 43 & - \\
\hline & IV & - & 97 & - & - \\
\hline & $\mathrm{V}$ & - & 3 & - & - \\
\hline & VI & - & - & - & 24 \\
\hline & VII & - & - & - & 10 \\
\hline
\end{tabular}

\footnotetext{
${ }^{1}$ Mesophilic, $20-45^{\circ} \mathrm{C}$.

${ }^{2}$ Thermophilic, $>40^{\circ} \mathrm{C}$.

${ }^{3}$ Substrate types: slaughterhouse waste (I), source-separated organic household waste (II), food processing waste (III), distiller's waste from ethanol production (IV), cereals (V), silage (VI), and sludge from grease traps (VIII).
}

$\mathrm{Cu}$ and $\mathrm{Zn}$, are conforming to the guideline for soil improvers according to the "EU Ecolabel" (http://ec.europa .eu/environment/ecolabel/; 21/11/14). The values for $\mathrm{Cu}$ and $\mathrm{Zn}$ are the same as for wastewater sludge which allowed for dispersion on arable land according to the Swedish Statute Book SFS 1998:944 (http://www .riksdagen.se/en/; 21/11/14). Approximately $10 \mathrm{~L}$ digestate was collected from each biogas plant according to the SPCR 120 rules for collecting samples for analysis and transported refrigerated. At arrival to the laboratory the digestate was thoroughly mixed before being portioned into small bottles and stored at $-20^{\circ} \mathrm{C}$ until use. The compositions of the main feedstock to each of the four biogas plant reactors, process temperatures, and retention times are presented in Table 2. Pig slurry (PS) was collected from a fattener pig farm with well-mixed slurry storage. The chemical and physical characteristics of the residues are given in Table 3. The $\mathrm{pH}$ was measured with a $\mathrm{pH}$ meter directly after agitating and without dilution (PHM 93 Reference $\mathrm{pH}$ Meter, Radiometer Medical, Brønshøy, Copenhagen, Denmark). Dry matter (DM) was determined according to SSEN 12880 [25], Tot-C according to ISO 10694 [26], and Tot$\mathrm{N}$ and organic $\mathrm{N}$ (Org-N) according to ISO 13878 [27]. Total phosphorus (Tot-P), total sulphur (Tot-S), and total amounts of the metals calcium $(\mathrm{Ca})$, potassium $(\mathrm{K})$, magnesium $(\mathrm{Mg})$, manganese $(\mathrm{Mn})$, mercury ( $\mathrm{Hg}), \mathrm{Cd}, \mathrm{Cr}, \mathrm{Cu}, \mathrm{Ni}, \mathrm{Pd}$, and $\mathrm{Zn}$ were all analyzed according to SS 28311 [28].

2.3. Experimental Setup. The soil was amended with each residue at a range of doses: $0.027,0.054,0.108,0.216,0.432$, 0.86 , and $1.7 \mathrm{mg} \mathrm{NH}{ }_{4}^{+}-\mathrm{Ng}^{-1}$ dry soil (ds), after which the microbial activity was measured directly. These doses corresponded to field application rates of 17.5, 35, 70, 140, 280,560 , and $1120 \mathrm{~kg} \mathrm{NH}_{4}{ }^{+}-\mathrm{N} \mathrm{ha}^{-1}$ assuming a field bulk density of $1.31 \mathrm{~g} \mathrm{~cm}^{-3}$ and a distribution depth of $5 \mathrm{~cm}$. To reach the desired soil moisture level in the assay or to allow the desired $\mathrm{N}$ rate to be provided, the residues were in some cases blended with appropriate amounts of deionized water
TABLE 3: Chemical and physical characteristics of the four different biogas digestates (BD-A, BD-B, BD-C, and BD-D) and pig slurry (PS) used in the experiments.

\begin{tabular}{|c|c|c|c|c|c|}
\hline Parameter & BD-A & BD-B & $\mathrm{BD}-\mathrm{C}$ & BD-D & PS \\
\hline$\overline{\mathrm{pH}}$ & 7.9 & 7.9 & 8 & 8.7 & 6.6 \\
\hline Dry matter, DM (\%) & 6.1 & 3.7 & 1.7 & 5.9 & 9.1 \\
\hline Tot-C ( $\left.\mathrm{g} \mathrm{kg}^{-1} \mathrm{ww}\right)$ & 19 & 9 & 7 & 24 & 40 \\
\hline Tot-N ( $\left.\mathrm{g} \mathrm{kg}^{-1} \mathrm{ww}\right)$ & 7.9 & 5.9 & 2.6 & 5.3 & 5.3 \\
\hline Org-N (g kg$\left.{ }^{-1} \mathrm{ww}\right)$ & 2.6 & 2.2 & 0.6 & 2.0 & 2.9 \\
\hline $\mathrm{NH}_{4}^{+}-\mathrm{N}\left(\mathrm{g} \mathrm{kg}^{-1} \mathrm{ww}\right)$ & 5.3 & 3.7 & 2.03 & 3.3 & 2.4 \\
\hline $\mathrm{C} / \mathrm{N}$ & 7.1 & 4.2 & 11.0 & 12.1 & 13.6 \\
\hline Tot-P (g kg$\left.{ }^{-1} \mathrm{ww}\right)$ & 0.9 & 0.7 & 0.2 & 0.4 & 1.4 \\
\hline $\mathrm{K}\left(\mathrm{g} \mathrm{kg}^{-1} \mathrm{ww}\right)$ & 1.6 & 2.8 & 1.1 & 3.7 & 2.5 \\
\hline $\mathrm{S}\left(\mathrm{g} \mathrm{kg}^{-1} \mathrm{ww}\right)$ & 0.60 & 1.22 & 0.12 & 0.26 & 0.47 \\
\hline $\operatorname{Mg}\left(\mathrm{g} \mathrm{kg}^{-1} \mathrm{ww}\right)$ & 0.2 & 0.1 & 0.1 & 0.3 & 0.6 \\
\hline $\mathrm{Ca}\left(\mathrm{g} \mathrm{kg}^{-1} \mathrm{ww}\right)$ & 0.6 & 0.1 & 0.3 & 1.3 & 1.7 \\
\hline $\mathrm{Cr}\left(\mathrm{mg} \mathrm{kg}^{-1} \mathrm{ww}\right)$ & 13.0 & 14.9 & 11.1 & 19.5 & 10.7 \\
\hline $\mathrm{Mn}\left(\mathrm{mg} \mathrm{kg}^{-1} \mathrm{ww}\right)$ & 201 & 266 & 91.8 & 286 & 426 \\
\hline $\mathrm{Ni}\left(\mathrm{mg} \mathrm{kg}^{-1} \mathrm{ww}\right)$ & 38.8 & 35.5 & 1.7 & 1.7 & 39.6 \\
\hline $\mathrm{Cu}\left(\mathrm{mg} \mathrm{kg}^{-1} \mathrm{ww}\right)$ & 69.7 & 69.4 & 39.8 & 97.4 & 218 \\
\hline $\mathrm{Zn}\left(\mathrm{mg} \mathrm{kg}^{-1} \mathrm{ww}\right)$ & 474 & 465 & 299 & 395 & 801 \\
\hline $\mathrm{Cd}\left(\mathrm{mg} \mathrm{kg}^{-1} \mathrm{ww}\right)$ & 0.3 & 0.3 & 1.2 & 0.3 & 0.3 \\
\hline $\mathrm{Pb}\left(\mathrm{mg} \mathrm{kg}^{-1} \mathrm{ww}\right)$ & 0.1 & 0.7 & 4.6 & 3.4 & 0.1 \\
\hline $\mathrm{Hg}\left(\mathrm{mg} \mathrm{kg}^{-1} \mathrm{ww}\right)$ & $<0.1$ & $<0.1$ & $<0.1$ & $<0.1$ & $<0.1$ \\
\hline
\end{tabular}

$\mathrm{ww}=$ wet weight.

prior to application to the soil. In addition, each microbial soil test contained a control without residue amendment.

\subsection{Microbiological Assays}

2.4.1. Soil Respiration. For determination of soil respiration, portions of thawed soil corresponding to $20 \mathrm{~g}$ ds were weighed into $250 \mathrm{~mL}$ airtight plastic jars and preincubated for two weeks at $20^{\circ} \mathrm{C}$ to allow the soil respiration to stabilize. The four BDs and the PS were subsequently added at rates 
corresponding to $17.5,35,70$, and $140 \mathrm{~kg} \mathrm{NH}_{4}{ }^{+}-\mathrm{N} \mathrm{ha}^{-1}$. The target moisture content of the soil after amendment was $65 \%$ of its water holding capacity (WHC). The high water content of the residues prevented amendment of the highest doses, corresponding to $280-1120 \mathrm{~kg} \mathrm{NH}_{4}{ }^{+}-\mathrm{N} \mathrm{ha}^{-1}$. The treatments corresponding to 17.5 and $35 \mathrm{~kg} \mathrm{NH}_{4}{ }^{+}-\mathrm{N} \mathrm{ha}^{-1}$ were replicated three times except for PS at $35 \mathrm{~kg} \mathrm{NH}_{4}{ }^{+}-\mathrm{Nha}^{-1}$, which was replicated four times due to uncertainties in adding this heterogeneous residue. The treatments 70 and $140 \mathrm{~kg} \mathrm{NH}_{4}{ }^{+}$$\mathrm{Nha}^{-1}$ were replicated four times and the nonamended control six times. In the soil respiration assay the digestates were spread evenly onto the surface of the soil sample by use of a $10 \mathrm{~mL}$ automate pipette. After addition the respiration jars were gently tapped against the table to allow gas exchange, to further distribute the digestate in the soil volume, and to achieve a more homogenous soil aggregate distribution. The respiration rate was monitored every 30 minutes for five days before amendment with residue to obtain basal respiration rates and then for 12 days after amendment. Evolution of $\mathrm{CO}_{2}$ collected in $0.3 \mathrm{M} \mathrm{KOH}$ solution was determined with a Respicond III instrument (Nordgren Innovations $\mathrm{AB}$, Umeå, Sweden) [29]. Basal respiration was determined by linear regression of the accumulated respiration data from the 5 days of incubation prior to the residue additions. The basal respiration rate was subtracted from the primary respiration rate recorded after residue amendment to give the residue-induced respiration rates. Characteristic data were then extracted from the residue-induced respiration curves obtained according to the ISO standard for evaluation of respiration curves [30]. Due to the differences between the ISO standard (which uses glucose as substrate) and the present experiment, not all the characteristic values given in the ISO standard could be obtained. The values actually obtained were (1) the time for the maximum respiration activity (main peak time, $t_{\text {peakmax }}$ ) and (2) the microbial specific growth rate $(\mu)$, derived from data transformed to the natural logarithmic scale. In addition, (3) the maximum respiration activity (main peak height, $h_{\text {peakmax }}$ ) and $(4)$ the total utilization rate ( $\%$ of added $\mathrm{C}$ converted to $\mathrm{CO}_{2}$ ) over the 12-day incubation were assessed.

2.4.2. Nitrogen Mineralization Capacity (NMC). The NMC assay was performed according to Waring and Bremner [31] as modified by Stenberg et al. [20]. In the assay, aliquots of $10 \mathrm{~g}$ ww thawed soil were placed in five $250 \mathrm{~mL}$ Duran flasks for each treatment. Different amounts of residue (representing $17.5-1120 \mathrm{~kg} \mathrm{NH}_{4}{ }^{+}-\mathrm{Nha}^{-1}$ ) were added to each set of five replicate flasks. The dose of digestate was distributed evenly onto the soil surface. After waiting 10 minutes to allow the digestate to absorb, each flask received deionized water to achieve a total addition of $25 \mathrm{~mL}$ water (including the water in the digestate, but not in the soil). The flasks were made anaerobic by evacuating and flushing them with pure nitrogen $\left(\mathrm{N}_{2}\right)$ five times to inhibit nitrification. The slurries were then incubated for 10 days at $37^{\circ} \mathrm{C}$. At the start, two flasks were sampled and after 10 days the remaining three flasks were sampled. At sampling, $25 \mathrm{~mL} 4 \mathrm{M} \mathrm{KCl}$ was added to the slurries and the flasks were placed on a shaker for $2 \mathrm{~h}$ (175 rpm), after which samples of $7.5 \mathrm{~mL}$ were withdrawn into test tubes. All the tubes were centrifuged for $3 \mathrm{~min}(4500 \mathrm{rpm})$ and the content filtered through a filter paper (Munktell, size 00A, Munktell Filter AB, Falun, Sweden). The filtrate was then analyzed for $\mathrm{NH}_{4}{ }^{+}$by flow injection analysis (FIAstar 5000 Analyzer, FOSS Analytical, Hilerød, Denmark). The accumulation of ammonium during 10 days (NMC) was calculated as the difference between mean amounts at the start and after 10 days. A supplementary NMC test was performed by also adding glucose yielding final substrate concentrations of $0,0.5$, and $1 \%$ (i.e., $0,0.5$, and $1 \mathrm{mg}$ glucose $\mathrm{mL}^{-1}$, resp.) to soil amended with doses of $\left(\mathrm{NH}_{4}\right)_{2} \mathrm{SO}_{4}$ or BD-D corresponding to $1120 \mathrm{~kg} \mathrm{NH}_{4}{ }^{+}-\mathrm{N} \mathrm{ha}^{-1}$.

2.4.3. Potential Ammonium Oxidation Rates (PAO). The PAO assay was performed according to Pell et al. [9] and ISO 15685 [32], and effects of amendment rates corresponding to 17.5-1120 kg NH${ }_{4}^{+}-\mathrm{N} \mathrm{ha}^{-1}$ were tested. In the assay, for each rate to be tested, $3 \times 25 \mathrm{~g}$ ww thawed soil was weighed into $250 \mathrm{~mL}$ Duran flasks. After distributing the dose of digestate evenly onto the soil and then waiting for 10 minutes for the digestate to be absorbed, substrate-potassium phosphate buffer and deionized water were added to reach a final volume of $100 \mathrm{~mL}$ (including the water in the digestate, but not in the soil). The final substrate in the assay contained $100 \mathrm{mM}$ phosphate buffer ( $\mathrm{pH} 7.2$ ); $0.4 \mathrm{mM}(\mathrm{NH} 4)_{2} \mathrm{SO}_{4}$; and $15 \mathrm{mM}$ $\mathrm{NaClO}_{3}$. Chlorate was used to inhibit the further conversion of nitrite to nitrate. The soil slurry was incubated on a rotary shaker $(175 \mathrm{rpm})$ at $+25^{\circ} \mathrm{C}$ for 6 hours. Slurry samples of $2 \mathrm{~mL}$ were withdrawn after 2 hours and, then once every hour, resulted in a total of five samples. The samples were placed into test tubes prefilled with $2 \mathrm{~mL}$ of $4 \mathrm{M} \mathrm{KCl}$ to stop ammonium oxidation. After each sampling occasion, the samples were centrifuged at $4500 \mathrm{rpm}$ for $3 \mathrm{~min}$ and the supernatant filtered through a filter paper (Munktell, size $00 \mathrm{~A})$. The filtrate was then analyzed for $\mathrm{NO}_{2}{ }^{-}$by flow injection analysis (FIAstar 5000 Analyzer). The ammonium oxidation rate (PAO) was calculated as the mean value $(n=3)$ from linear regression of accumulated nitrite in each flask over time.

2.4.4. Potential Denitrification Activity (PDA). PDA was assayed in amended soil according to the modified shortincubation $\mathrm{C}_{2} \mathrm{H}_{2}$-inhibition method described by Pell et al. [33] and effects of amendment rates corresponding to 17.5$1120 \mathrm{~kg} \mathrm{NH}_{4}{ }^{+}-\mathrm{N} \mathrm{ha}^{-1}$ were tested. In the assay, for each rate to be tested, $3 \times 25 \mathrm{~g} \mathrm{ww}$ thawed soil was weighed into $250 \mathrm{~mL}$ Duran flasks. The dose of digestate was distributed evenly onto the soil surface. After waiting 10 minutes to allow the digestate to absorb, each flask was supplied with deionized water and substrate solution to achieve a total addition of $25 \mathrm{~mL}$ water (including the water in the digestate, but not in the soil). The substrate solution contained glucose and $\mathrm{KNO}_{3}$, and the final concentration of these in the $25 \mathrm{~mL}$ slurry solution was $1 \mathrm{mM}$. Each residue was assayed in separate experimental sessions with a control treatment replicated three times included where only autoclaved water (equivalent to that in the residue) and substrate solution were added 
to the soil. After addition of the substrate solution, the flasks were sealed and then evacuated and flushed with $\mathrm{N}_{2}$ five times. Then, $25 \mathrm{~mL}$ of acetylene was injected to inhibit the reduction of $\mathrm{N}_{2} \mathrm{O}$ to $\mathrm{N}_{2}$, after which the flasks were placed on a shaker at $175 \mathrm{rpm}$ at a constant temperature of $+25^{\circ} \mathrm{C}$. During the assay, seven $0.5 \mathrm{~mL}$ gas samples were collected from the flask head space and injected into gastight $20 \mathrm{~mL}$ glass vials. The first sample was withdrawn 15 minutes after acetylene injection and then every 30 minutes. All samples were analyzed by a gas chromatograph equipped with an electron capture detector (Perkin Elmer Clarus 500, Waltham, MA, USA). The rate of $\mathrm{N}_{2} \mathrm{O}$ formation increased with time and the data were fitted by nonlinear regression to a product-formation equation that takes exponential growth into consideration [34] to yield the initial product formation rate (PDA; mean value, $n=3$ ).

In order to further explain the results of the PDA experiment and to validate the PDA method, a follow-up experiment was performed. This experiment included (1) a control treatment identical to the original PDA assay as described above, (2) a control treatment supplied with $6.25 \mathrm{~mL}$ of a trace element solution according to CohenBazire et al. [35], and (3) a control treatment with double concentration of glucose $(2 \mathrm{mM})$. The trace element solution consisted of $0.25 \mathrm{mg} \mathrm{L}^{-1} \quad \mathrm{Na}_{2} \mathrm{MoO}_{4} \cdot 2 \mathrm{H}_{2} \mathrm{O}, \quad 10.95 \mathrm{mg} \mathrm{L}^{-1}$ $\mathrm{ZnSO}_{4} \cdot 7 \mathrm{H}_{2} \mathrm{O}, \quad 5.00 \mathrm{mg} \mathrm{L}^{-1} \quad \mathrm{FeSO}_{4} \cdot 7 \mathrm{H}_{2} \mathrm{O}, \quad 1.54 \mathrm{mg} \mathrm{L}^{-1}$ $\mathrm{MnSO}_{4} \cdot \mathrm{H}_{2} \mathrm{O}, \quad 0.39 \mathrm{mg} \mathrm{L}^{-1} \quad \mathrm{CuSO}_{4} \cdot 5 \mathrm{H}_{2} \mathrm{O}, \quad 0.20 \mathrm{mg} \mathrm{L}^{-1}$ $\mathrm{CoCl}_{2} \cdot 6 \mathrm{H}_{2} \mathrm{O}$, and $0.17 \mathrm{mg} \mathrm{L}^{-1} \mathrm{Na}_{2} \mathrm{~B}_{4} \mathrm{O}_{7} \cdot 10 \mathrm{H}_{2} \mathrm{O}$. All three treatments were replicated three times. In addition, a nonreplicated treatment (4) was performed where PS was heat-treated at $80^{\circ} \mathrm{C}$ for 15 minutes to denature enzymes and kill any bacteria present before addition to the soil and a standard PDA assay was performed. The PS amendment corresponded to $1120 \mathrm{~kg} \mathrm{NH}_{4}^{+}-\mathrm{N} \mathrm{ha}^{-1}$.

2.5. Data Treatment and Statistical Analyses. Soil respiration data were analyzed by analysis of variance using JMP version 9.0.0 (SAS Institute Inc., Cary, NC, USA) where residue type, residue rates, and residue type $\times$ residue rate interaction were considered as fixed factors. The Tukey (HSD) multiple comparison test was used for repeated testing of paired differences between treatments. Nitrogen mineralization data (NMC) are reported as mean values at different doses with standard deviation. The PAO and PDA responses to the increasing doses of the residues were plotted using SigmaPlot version 8.0 (Systat Software Inc., San José, CA, USA) and fitted with a four parameter logistic model:

$$
A=A_{\min }+\frac{A_{\max }-A_{\min }}{1+\left(c / \mathrm{EC}_{50}\right)^{-H}},
$$

where $A$ is the measured activity, $A_{\max }$ is the maximum activity (with no residue addition), $A_{\min }$ is the lowest theoretical activity (at infinite residue addition), $c$ is the amendment rate, $\mathrm{EC}_{50}$ is the amendment rate that gives $50 \%$ activity, and $\mathrm{H}$ is the Hill coefficient. The effect concentrations lowering PAO and PDA by $10 \%\left(\mathrm{EC}_{10}\right)$ and $90 \%\left(\mathrm{EC}_{90}\right)$ were calculated from the values obtained in the nonlinear regression. High $R^{2}$ values of the regression indicated a good fit and are presented
TABLE 4: Amount of dry matter (DM), heavy metals, and nutrients added at an amendment rate corresponding to $70 \mathrm{~kg} \mathrm{NH}_{4}^{+}-\mathrm{N} \mathrm{ha}^{-1}$ with the four types of biogas digestates (BD-A, BD-B, BD-C, and BD-D) and pig slurry (PS).

\begin{tabular}{lccccc}
\hline Parameter & BD-A & BD-B & BD-C & BD-D & PS \\
\hline $\mathrm{DM}\left(\mathrm{kg} \mathrm{ha}^{-1}\right)$ & 854 & 632 & 425 & 1180 & 2650 \\
Tot-C $\left(\mathrm{kg} \mathrm{ha}^{-1}\right)$ & 266 & 154 & 175 & 480 & 1170 \\
Tot-N $\left(\mathrm{kg} \mathrm{ha}^{-1}\right)$ & 106 & 109 & 85 & 110 & 155 \\
Org-N $\left(\mathrm{kg} \mathrm{ha}^{-1}\right)$ & 36 & 38 & 15 & 40 & 85 \\
$\mathrm{NH}_{4}^{+}-\mathrm{N}\left(\mathrm{kg} \mathrm{ha}^{-1}\right)$ & 70 & 70 & 70 & 70 & 70 \\
$\mathrm{Cr}\left(\mathrm{g} \mathrm{ha}^{-1}\right)$ & 182 & 254 & 277.5 & 390 & 312 \\
$\mathrm{Mn}\left(\mathrm{g} \mathrm{ha}^{-1}\right)$ & 2810 & 4540 & 2300 & 5730 & 12400 \\
$\mathrm{Ni}\left(\mathrm{g} \mathrm{ha}^{-1}\right)$ & 543 & 606 & 42.5 & 34 & 1160 \\
$\mathrm{Cu}\left(\mathrm{g} \mathrm{ha}^{-1}\right)$ & 976 & 1190 & 995 & 1950 & 6360 \\
$\mathrm{Zn}\left(\mathrm{g} \mathrm{ha}^{-1}\right)$ & 6640 & 7940 & 7480 & 7910 & 23400 \\
$\mathrm{Cd}\left(\mathrm{g} \mathrm{ha}^{-1}\right)$ & 4.2 & 5.1 & 30 & 6.0 & 8.8 \\
$\mathrm{~Pb}\left(\mathrm{~g} \mathrm{ha}^{-1}\right)$ & 1.4 & 12.0 & 115 & 68 & 2.9 \\
$\mathrm{Hg}\left(\mathrm{g} \mathrm{ha}^{-1}\right)$ & 1.4 & 1.7 & 2.5 & 2.0 & 2.9 \\
\hline
\end{tabular}

together with the EC-values in Table 6. In the PDA followup experiment, Student's $t$-test was performed to reveal any significant differences. Differences between treatments in all statistical analyses were deemed statistically significant at $P<$ 0.05 unless otherwise stated.

\section{Results}

3.1. Chemical Properties of the Organic Residues Applied to Soil. Overall, the content of Tot-C and Org-N was lower in the BDs than in PS (Table 3). However, all BDs except for BD-C had a higher concentration of $\mathrm{NH}_{4}{ }^{+}-\mathrm{N}$ than the PS. The amounts of dry matter, plant nutrients, and heavy metals added with each residue at rates corresponding to $70 \mathrm{~kg} \mathrm{NH}{ }_{4}^{+}-\mathrm{Nha}^{-1}$ are shown in Table 4. As nutrient addition with the amendments was calculated on the basis of their $\mathrm{NH}_{4}{ }^{+}-\mathrm{N}$ level, the PS treatments generally received more Tot- $\mathrm{C}$ than the $\mathrm{BD}$ treatments. The dry matter added with the $70 \mathrm{~kg} \mathrm{NH}_{4}{ }^{+}-\mathrm{N} \mathrm{ha}^{-1}$ dose varied between 425 and $1180 \mathrm{~kg} \mathrm{ha}^{-1}$ for the BDs, while it was $2650 \mathrm{~kg} \mathrm{ha}^{-1}$ for PS. The corresponding amounts of Tot-C and Org-N were 154-480 and $15-40 \mathrm{~kg} \mathrm{ha}^{-1}$, respectively, in the different BDs and 1170 and $85 \mathrm{~kg} \mathrm{ha}^{-1}$ in PS. The amounts of $\mathrm{Mn}, \mathrm{Ni}, \mathrm{Cu}, \mathrm{Zn}$, and $\mathrm{Hg}$ added were higher with the PS than the BDs, whereas the application of $\mathrm{BD}-\mathrm{C}$ and $\mathrm{BD}-\mathrm{D}$ resulted in the highest doses of $\mathrm{Cd}, \mathrm{Pb}$, and $\mathrm{Cr}$, respectively.

3.2. Soil Respiration. The varying $\mathrm{C}$ concentrations in the residues in combination with the increasing doses led to different amounts of $\mathrm{C}$ being respired (Table 5). At the lowest dose, corresponding to $17.5 \mathrm{~kg} \mathrm{NH}_{4}{ }^{+}-\mathrm{N} \mathrm{ha}^{-1}$, the amounts of $\mathrm{C}$ respired were very low for some of the residues and the background "noise" of the respirometer prevented extraction of some of the characteristic respiration values. However, the two highest amendment rates (i.e., corresponding to 70 and $140 \mathrm{~kg} \mathrm{NH}_{4}{ }^{+}-\mathrm{N} \mathrm{ha}^{-1}$ ) provided clear and reliable signals 
TABLE 5: Calculated parameters from soil respiration curves after amendment with four types of biogas digestates (BD-A, BD-B, BD-C, and BD-D) and pig slurry (PS). $t_{\text {peakmax }}$ is the time of maximum respiration activity after amendment and the maximum peak height $\left(h_{\text {peakmax }}\right)$ is the respiration rate at that time. Specific growth rate $(\mu)$ was calculated according to ISO/DIS 17155 (i.e., on a $\log _{10}$ basis). The C utilization rate is the cumulative respired $\mathrm{C}$ during the 12 days of incubation. Values not sharing the same letters (a-e) are statistical significantly different $(P<0.05)$.

\begin{tabular}{|c|c|c|c|c|c|}
\hline Residue type & $\begin{array}{l}\text { Amendment rate } \\
\left(\mathrm{kg} \mathrm{NH}_{4}^{+}-\mathrm{N} \mathrm{ha}^{-1}\right)\end{array}$ & $t_{\text {peakmax }}(\mathrm{h})$ & $h_{\text {peakmax }}\left(\mathrm{mg} \mathrm{CO}_{2} \mathrm{~h}^{-1}\right)$ & Specific growth rate $(\mu)$ & $\begin{array}{c}\text { Utilization rate of } \\
\text { C } \\
(\% \text { of added } C)\end{array}$ \\
\hline \multirow{4}{*}{ BD-A } & 17.5 & $55.0^{c}$ & $0.046^{\mathrm{e}}$ & $0.013^{\mathrm{d}}$ & $39.8^{\mathrm{a}}$ \\
\hline & 35 & $57.4^{\mathrm{b}}$ & $0.078^{\mathrm{de}}$ & $0.017^{\mathrm{d}}$ & $28.5^{\mathrm{abc}}$ \\
\hline & 70 & $62.1^{\mathrm{b}}$ & $0.141^{\mathrm{de}}$ & $0.017^{\mathrm{d}}$ & $30.9^{\mathrm{ab}}$ \\
\hline & 140 & $66.2^{\mathrm{a}}$ & $0.287^{\mathrm{d}}$ & $0.019^{\mathrm{d}}$ & $32.5^{\mathrm{ab}}$ \\
\hline \multirow{4}{*}{$\mathrm{BD}-\mathrm{B}$} & 17.5 & - & - & - & $-^{2}$ \\
\hline & 35 & $\leq 8.5^{1}$ & $\geq 0.068^{1}$ & - & $21.8^{\mathrm{bcd}}$ \\
\hline & 70 & $18.4^{\mathrm{f}}$ & $0.117^{\mathrm{de}}$ & $0.018^{\mathrm{d}}$ & $16.6^{\mathrm{d}}$ \\
\hline & 140 & $19.6^{\mathrm{f}}$ & $0.259^{\mathrm{de}}$ & $0.022^{\mathrm{d}}$ & $19.0^{\mathrm{cd}}$ \\
\hline \multirow{4}{*}{$\mathrm{BD}-\mathrm{C}$} & 17.5 & - & - & - & $-^{2}$ \\
\hline & 35 & $\leq 8.5^{1}$ & $\geq 0.175^{1}$ & - & $13.7^{\mathrm{d}}$ \\
\hline & 70 & $14.6^{\mathrm{g}}$ & $0.249^{\mathrm{de}}$ & $0.067^{\mathrm{bc}}$ & $19.4^{\mathrm{cd}}$ \\
\hline & 140 & $18.1^{\mathrm{f}}$ & $0.668^{\mathrm{c}}$ & $0.057^{\mathrm{bc}}$ & $30.9^{\mathrm{ab}}$ \\
\hline \multirow{4}{*}{ BD-D } & 17.5 & $\leq 8.5^{1}$ & $\geq 0.037^{1}$ & - & $13.7^{\mathrm{d}}$ \\
\hline & 35 & $\leq 8.5^{1}$ & $\geq 0.088^{1}$ & - & $15.7^{\mathrm{cd}}$ \\
\hline & 70 & $\leq 8.5^{1}$ & $\geq 0.202^{1}$ & - & $15.0^{\mathrm{d}}$ \\
\hline & 140 & $\leq 8.5^{1}$ & $\geq 0.405^{1}$ & - & $16.9^{\mathrm{d}}$ \\
\hline \multirow{4}{*}{ PS } & 17.5 & $12.6^{\mathrm{g}}$ & $0.232^{\mathrm{de}}$ & $0.090^{\mathrm{a}}$ & $32.2^{\mathrm{ab}}$ \\
\hline & 35 & $20.8^{\mathrm{f}}$ & $0.519^{c}$ & $0.053^{c}$ & $27.8^{\mathrm{abc}}$ \\
\hline & 70 & $29.2^{\mathrm{e}}$ & $1.111^{\mathrm{b}}$ & $0.060^{\mathrm{bc}}$ & $31.1^{\mathrm{ab}}$ \\
\hline & 140 & $36.5^{\mathrm{d}}$ & $2.233^{\mathrm{a}}$ & $0.074^{\mathrm{ab}}$ & $31.4^{\mathrm{ab}}$ \\
\hline
\end{tabular}

$\overline{{ }^{1} \text { Maximum respiration occurred before or at time of stabilization of the respirometer readings. Average values from the first reliable reading (at } 8.5 \mathrm{~h} \text { ) are }}$ reported but were not used in the statistical tests.

${ }^{2}$ Data points in the respiration measurements were frequently below the detection limit.

-: Data not obtainable.

TABLE 6: Effect concentrations lowering potential ammonia oxidation rate (PAO) and potential denitrification activity (PDA) in the soil by 10,50 , and $90 \%\left(\mathrm{EC}_{10}, \mathrm{EC}_{50}\right.$, and $\left.\mathrm{EC}_{90}\right)$ in response to addition of four types of biogas digestates $(\mathrm{BD}-\mathrm{A}, \mathrm{BD}-\mathrm{B}, \mathrm{BD}-\mathrm{C}$, and $\mathrm{BD}-\mathrm{D})$ and pig slurry (PS).

\begin{tabular}{|c|c|c|c|c|c|c|}
\hline \multirow{2}{*}{ Test } & \multirow{2}{*}{ Effect parameter } & \multicolumn{5}{|c|}{ Residue type } \\
\hline & & $\mathrm{BD}-\mathrm{A}$ & $\mathrm{BD}-\mathrm{B}$ & $\mathrm{BD}-\mathrm{C}$ & $\mathrm{BD}-\mathrm{D}$ & PS \\
\hline \multirow{4}{*}{$\mathrm{PAO}$} & $\mathrm{EC}_{10}\left(\mathrm{~kg} \mathrm{NH}_{4}^{+}-\mathrm{N} \mathrm{ha}^{-1}\right)$ & 136 & 30 & 98 & 271 & 20 \\
\hline & $\mathrm{EC}_{50}\left(\mathrm{~kg} \mathrm{NH}_{4}^{+}-\mathrm{N} \mathrm{ha}^{-1}\right)$ & 140 & 45 & 156 & 291 & 50 \\
\hline & $\mathrm{EC}_{90}\left(\mathrm{~kg} \mathrm{NH}_{4}^{+}-\mathrm{N} \mathrm{ha}^{-1}\right)$ & 144 & 68 & 250 & 312 & 128 \\
\hline & $R^{2}$ of nonlinear regression & 0.99 & 0.98 & 0.99 & 0.93 & 1.00 \\
\hline \multirow{4}{*}{ PDA } & $\mathrm{EC}_{10}\left(\mathrm{~kg} \mathrm{NH}_{4}^{+}-\mathrm{N} \mathrm{ha}^{-1}\right)$ & 141 & 120 & 87 & 55 & $\mathrm{n} / \mathrm{a}$ \\
\hline & $\mathrm{EC}_{50}\left(\mathrm{~kg} \mathrm{NH}_{4}^{+}-\mathrm{N} \mathrm{ha}^{-1}\right)$ & 318 & 287 & 346 & 238 & $\mathrm{n} / \mathrm{a}$ \\
\hline & $\mathrm{EC}_{90}\left(\mathrm{~kg} \mathrm{NH}_{4}^{+}-\mathrm{N} \mathrm{ha}^{-1}\right)$ & 714 & 685 & 1381 & 1029 & $\mathrm{n} / \mathrm{a}$ \\
\hline & $R^{2}$ of nonlinear regression & 0.98 & 0.98 & 0.97 & 0.98 & $\mathrm{n} / \mathrm{a}$ \\
\hline
\end{tabular}

$\mathrm{n} / \mathrm{a}=$ values not obtainable (no inhibitory effect).

(Figure 1). Nevertheless, for BD-D, $t_{\text {peakmax }}$ and $h_{\text {peakmax }}$ could only be approximated because of a very early maximum respiration activity in this treatment.

Increasing rates of amendment generally yielded significantly later peak times $\left(t_{\text {peakmax }}\right)$ and taller peaks $\left(h_{\text {peakmax }}\right)$
(Table 5). At 70 and $140 \mathrm{~kg} \mathrm{NH}_{4}{ }^{+}-\mathrm{Nha}^{-1}$, addition of BDA resulted in the highest $t_{\text {peakmax }}$, followed by PS. The differences in $t_{\text {peakmax }}$ between $\mathrm{BD}-\mathrm{A}, \mathrm{BD}-\mathrm{B}, \mathrm{BD}-\mathrm{C}$, and $\mathrm{PS}$ were statistically significant, except between $\mathrm{BD}-\mathrm{B}$ and $\mathrm{BD}-\mathrm{C}$ at $140 \mathrm{~kg} \mathrm{NH}_{4}{ }^{+}-\mathrm{N} \mathrm{ha}^{-1}$. For BD-D, $t_{\text {peakmax }}$ occurred before 
the start of the readings and thus was not considered in the statistical analysis. The $h_{\text {peakmax }}$ was considerably taller for PS than for any BD. However, the maximum respiration rate expressed as percentage of applied $\mathrm{C}$ was highest for $\mathrm{BD}-\mathrm{C}$ (Figure 1). The specific growth rate $(\mu)$ and the $\mathrm{C}$ utilization rate were generally not affected by the amendment rate (Table 5). The highest $\mu$ was observed for PS and $\mathrm{BD}$ $\mathrm{C}$ and the lowest for $\mathrm{BD}-\mathrm{A}$ and $\mathrm{BD}-\mathrm{B}$, but again, it could not be determined accurately for $\mathrm{BD}-\mathrm{D}$ as the respiration peak seemed to have occurred already before the stabilization of the respirometer readings at the start of the experiment (Figure 1). The utilization rate of $\mathrm{C}$ over the 12 days was higher for $\mathrm{BD}-\mathrm{A}$ and $\mathrm{PS}$, with values ranging between 27.8 and $39.8 \%$, and lower for BD-D, with values ranging between 13.7 and $16.9 \%$.

3.3. Nitrogen Mineralization Capacity. Overall, two trends in NMC were observed after amendment with increasing amounts of residue (Figure 2). Up to a certain application rate, increasing rates of $\mathrm{BD}$ resulted in decreasing NMC. Negative values were observed with all BDs at doses corresponding to $70 \mathrm{~kg} \mathrm{NH}_{4}{ }^{+}-\mathrm{Nha}^{-1}$. However, at application rates above $70-280 \mathrm{~kg} \mathrm{NH}_{4}{ }^{+}-\mathrm{N} \mathrm{ha}^{-1}$ a pronounced trend of increasing NMC with increasing dose was observed. Soil amended with PS showed positive NMC at all rates and at the highest rate PS displayed the highest NMC of all residues tested $\left(1254 \mu \mathrm{g} \mathrm{NH}_{4}{ }^{+}-\mathrm{N} \mathrm{g}^{-1} \mathrm{ds} 10 \mathrm{~d}^{-1}\right)$. Adding glucose along with the highest dose of $\mathrm{BD}-\mathrm{D}$ and $\left(\mathrm{NH}_{4}\right)_{2} \mathrm{SO}_{4}$ resulted in a transition from positive to negative NMC (data not shown).

3.4. Potential Ammonium Oxidation Rates. PAO was negatively correlated with the amendment rate for all residues, starting at rates corresponding to $17.5-140 \mathrm{~kg} \mathrm{NH}_{4}{ }^{+}-\mathrm{N} \mathrm{ha}^{-1}$ depending on the residue type (Figure 3 ). The negative responses were dose-dependent, with $\mathrm{BD}-\mathrm{B}$ and PS displaying the strongest negative responses. $\mathrm{EC}_{10}, \mathrm{EC}_{50}$, and $\mathrm{EC}_{90}$ for all tested residues ranged between 30-271, 45-291, and 68-312 kg N ha ${ }^{-1}$, respectively (Table 6). Digestates BD-A and $\mathrm{BD}-\mathrm{D}$ that originated from mesophilic biogas processes had higher $\mathrm{EC}_{10}$ values than $\mathrm{BD}-\mathrm{B}$ and $\mathrm{BD}-\mathrm{C}$ generated in thermophilic processes and PS.

3.5. Potential Denitrification Activity. All the residues induced a slight positive response in PDA at low doses, which means that the activity of the denitrifying enzymes was higher at these doses than in the control (Figure 4). Higher doses than $70 \mathrm{~kg} \mathrm{NH_{4 }}{ }^{+}-\mathrm{Nha}^{-1}$ of the four BDs resulted in a logarithmic decrease in the PDA. The $\mathrm{EC}_{10}$, $\mathrm{EC}_{50}$, and $\mathrm{EC}_{90}$ for each residue are shown in Table 6. The $\mathrm{EC}_{10}$ values of $\mathrm{BD}-\mathrm{D}$ but also $\mathrm{BD}-\mathrm{C}$ were lower than the corresponding values of the other two BDs. The PS induced a different response pattern in comparison with the $\mathrm{BD}$, in that PDA increased proportionally with the PS amendment rate. In the PDA follow-up experiment, neither trace element addition nor extra glucose in the assay solution led to higher PDA compared with the control without any addition ( $t$-test; $P<0.05)$. Amendment with heat-treated PS at rates corresponding to $1120 \mathrm{~kg} \mathrm{NH}_{4}{ }^{+}-\mathrm{N} \mathrm{ha}^{-1}$ resulted in a considerably lower PDA than amendment with nonheat-treated PS (4 versus $12 \mathrm{ng} \mathrm{N}_{2} \mathrm{O}-\mathrm{N} \mathrm{g}^{-1}$ ds $\mathrm{min}^{-1}$, resp.).

\section{Discussion}

In arable cropping systems, organic fertilizers are generally applied according to their content of easily available $\mathrm{N}$. Therefore, using the mineral $\mathrm{N}$ content as the basis for calculating the application rate should be a realistic approach for evaluating and comparing the quality of organic residues and their impact on the soil microbial ecosystem. With such an approach the amounts of $\mathrm{C}$ added will vary depending on the $\mathrm{C}$ content of the residue, which must be considered when evaluating the data.

4.1. Soil Respiration. All treatments displayed increasing main peak heights $\left(h_{\text {peakmax }}\right)$ and main peak times $\left(t_{\text {peakmax }}\right)$ with increasing amounts of residue added. Peak heights were 10-30\% higher after amendment with pig slurry compared with the BD treatments, which was most likely an effect of the 2.3-6.7 times higher Tot-C addition. However, $h_{\text {peakmax }}$ did not seem to reflect the total $C$ content among the different biogas digestates in any apparent way. The BD-D treatment which resulted in the highest addition of $\mathrm{C}$ displayed a relatively small $h_{\text {peakmax }}$ reflecting its small maximum respiration rate as a percentage of applied $\mathrm{C}$. The $\mathrm{BD}-\mathrm{A}$ and $\mathrm{BD}$ $\mathrm{C}$ treatments, which provided roughly the same amount of C, gave distinctly different respiration patterns. Generally, higher amendment rates did not seem to have any effects on soil respiratory efficiency as indicated by the similar specific growth and utilization rates recorded (Table 5). One exception to this was the utilization rate of $\mathrm{BD}-\mathrm{C}$ that was doubled at the highest amendment rate.

As would be expected from the wide variety of substrates that were used to feed the biogas plant reactors, differences in biodegradability between the different amendments were apparent from a number of the respiratory characteristic values measured. For example, early respiration peaks seemed to occur in the BD-A and BD-D treatments, even before the stabilization of the respirometer readings at the start of the experiment. It is likely that such early peaks were due to a high fraction of microbiologically accessible soluble organic $\mathrm{C}$ in these treatments, leading to a flush in $\mathrm{CO}_{2}$ production immediately after addition as reported by Alburquerque et al. [36] and Marstorp [37]. In fact, these digestates both originated from biogas plant reactors operating at low temperature (mesophilic) and BD-D from a plant with a short retention time, that is, conditions less favorable for degradation of organic components [38].

The overall utilization rate, that is, the degree of mineralization of the organic $\mathrm{C}$ added with the BDs and PS during 12 days, ranged between 15.0 and $32.5 \%$ for the two highest doses. This fell within the range found in the literature for a period of 12-14 days after application of digested materials to soil. Kirchmann and Lundvall [39] thus reported utilization ranging between 20 and $30 \%$ of the $\mathrm{C}$ in digested animal manures, while De Neve et al. [40] and de la Fuente et al. 


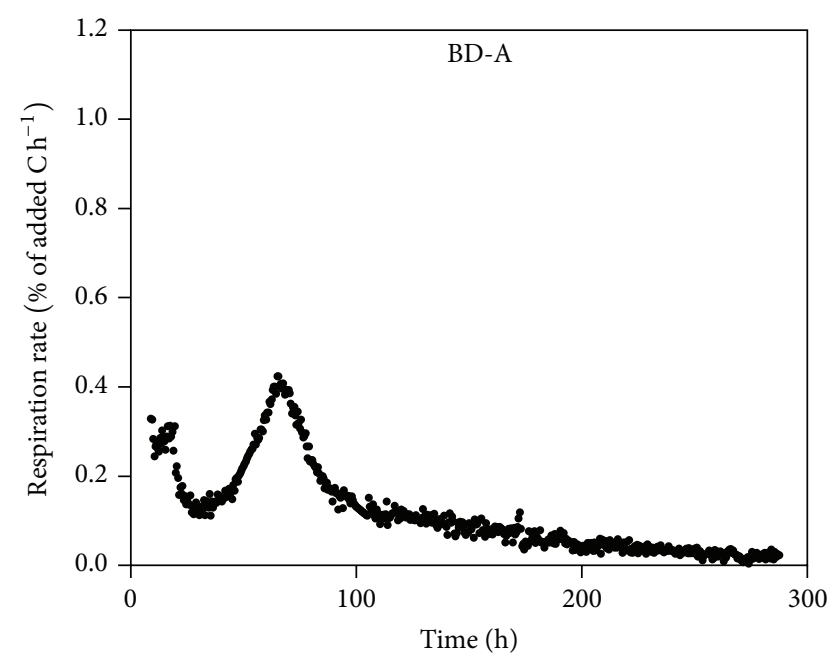

(a)

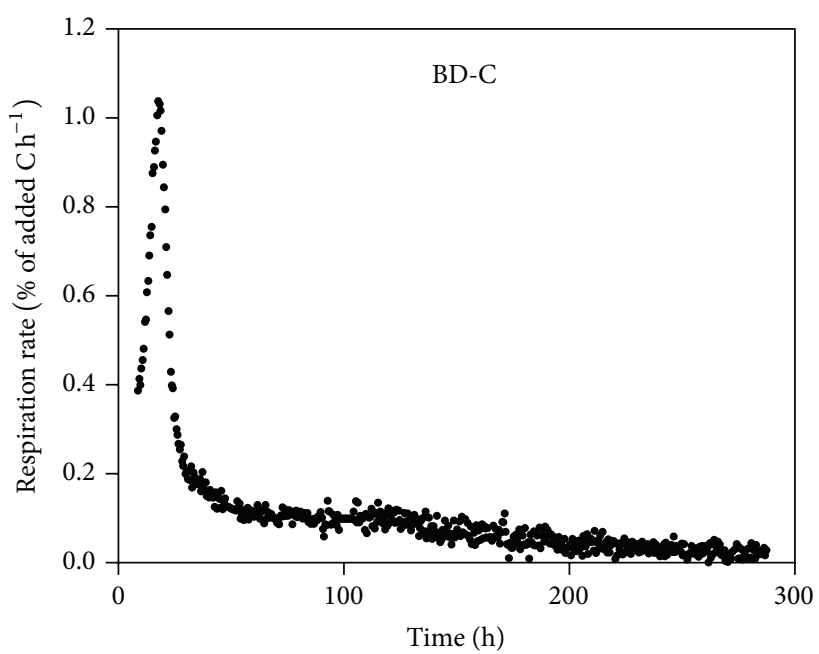

(c)

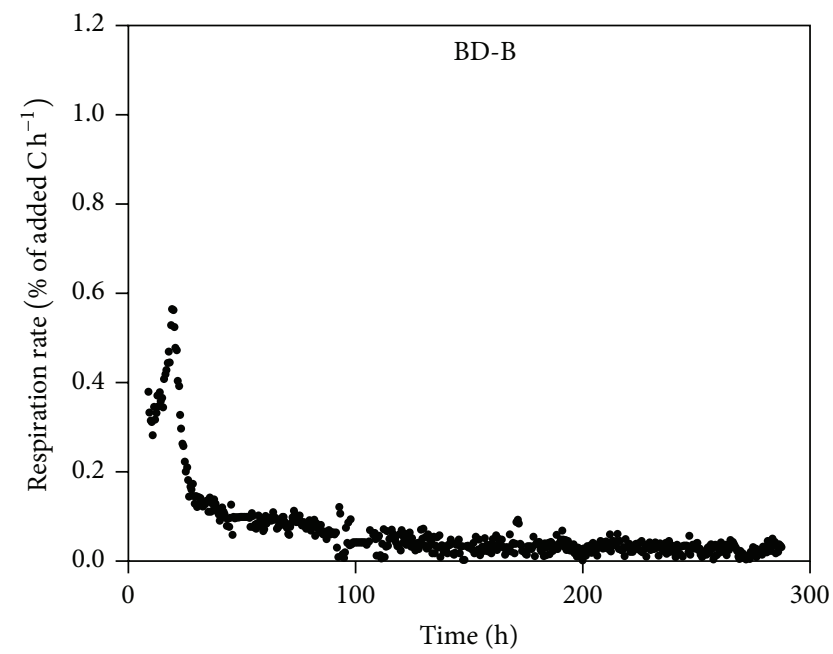

(b)

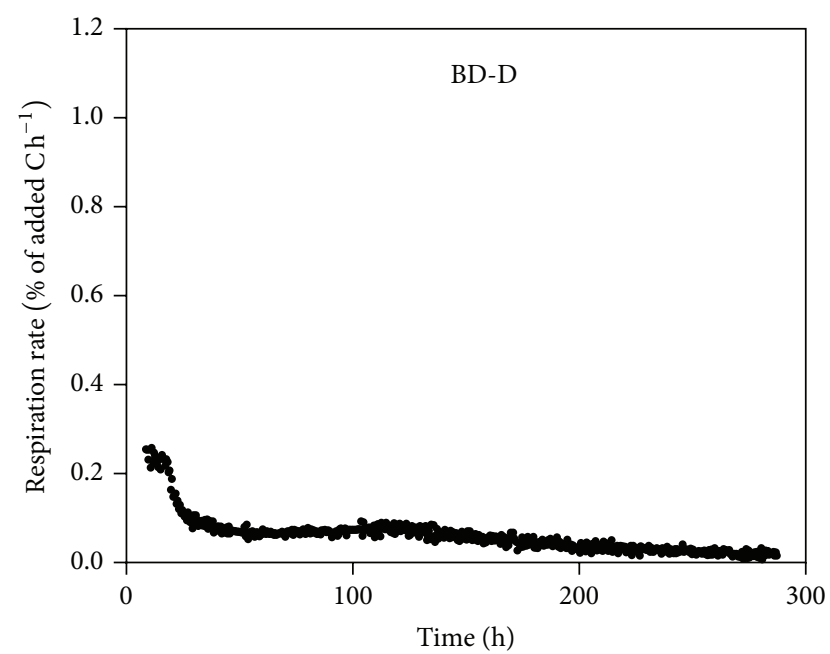

(d)

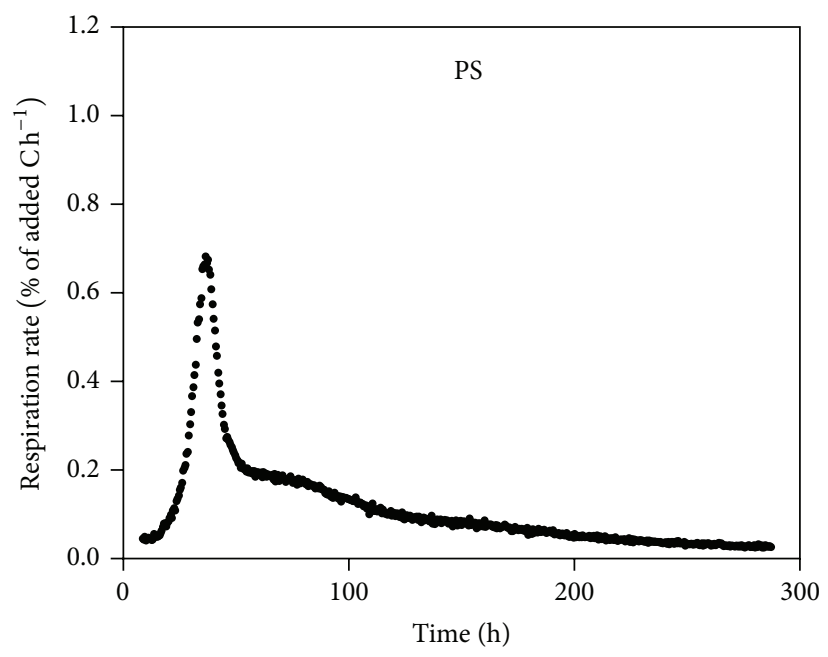

(e)

FIGURE 1: Soil respiration rate after amendment with four types of biogas residues (BD-A, BD-B, BD-C, and BD-D) and pig slurry (PS) at rates corresponding to $140 \mathrm{~kg} \mathrm{NH}_{4}{ }^{+}-\mathrm{N} \mathrm{ha}^{-1}$ (mean, $n=4$ ). 


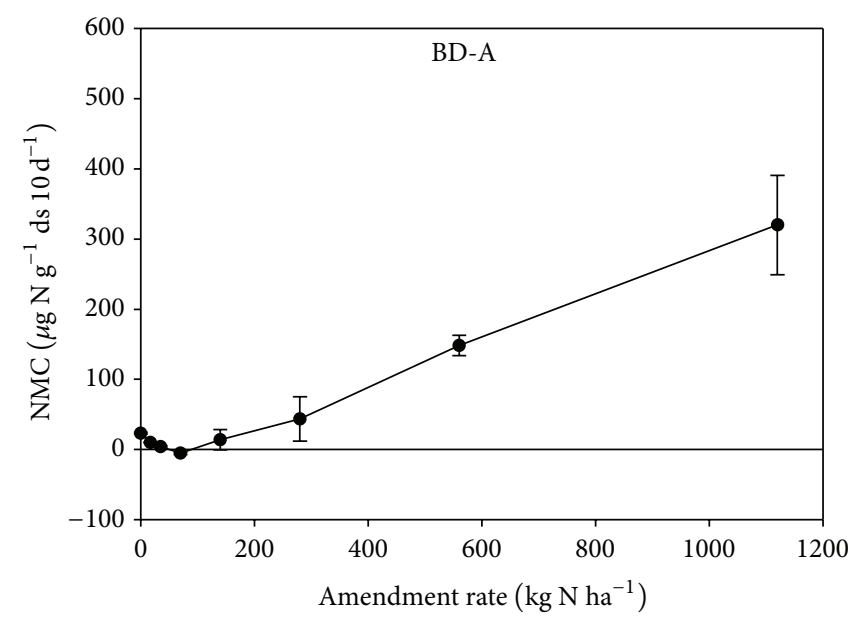

(a)

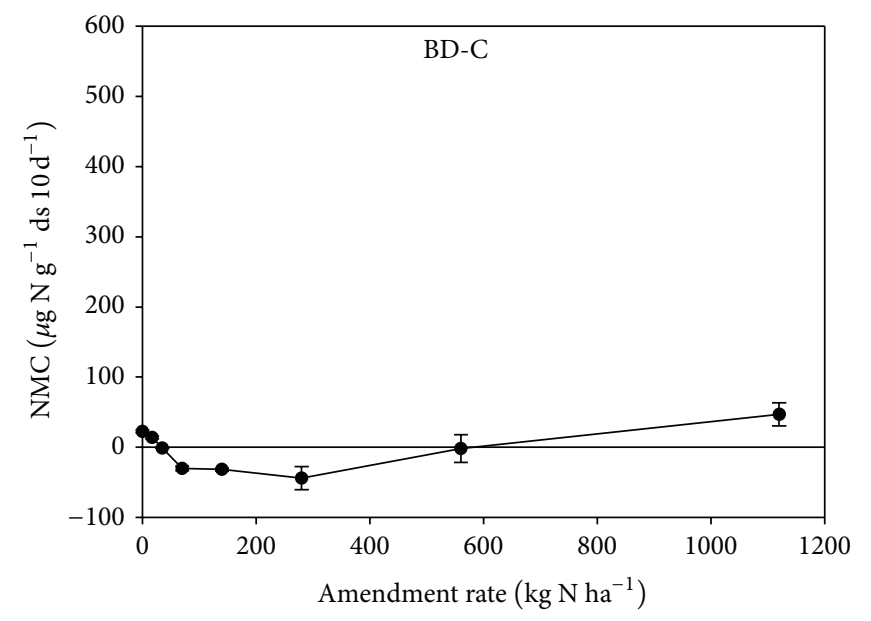

(c)

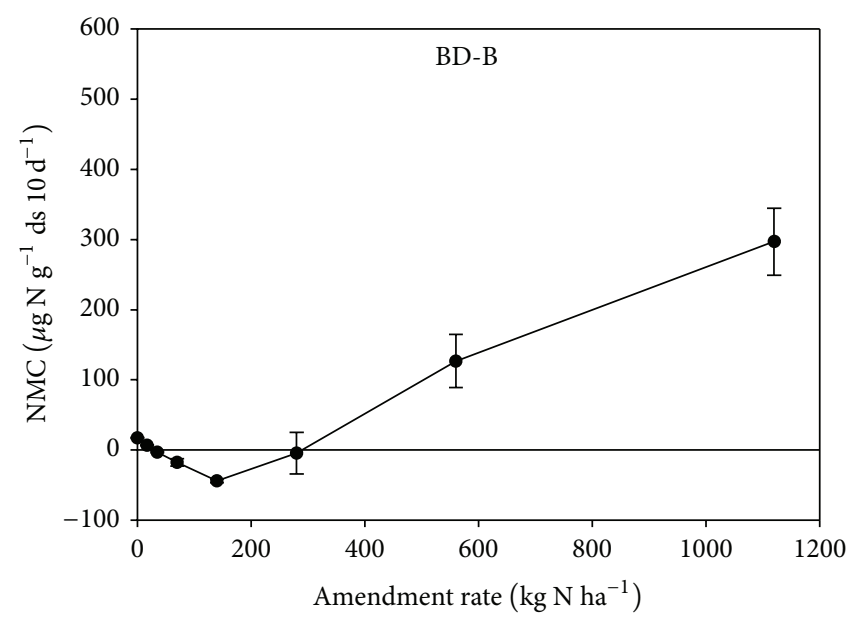

(b)

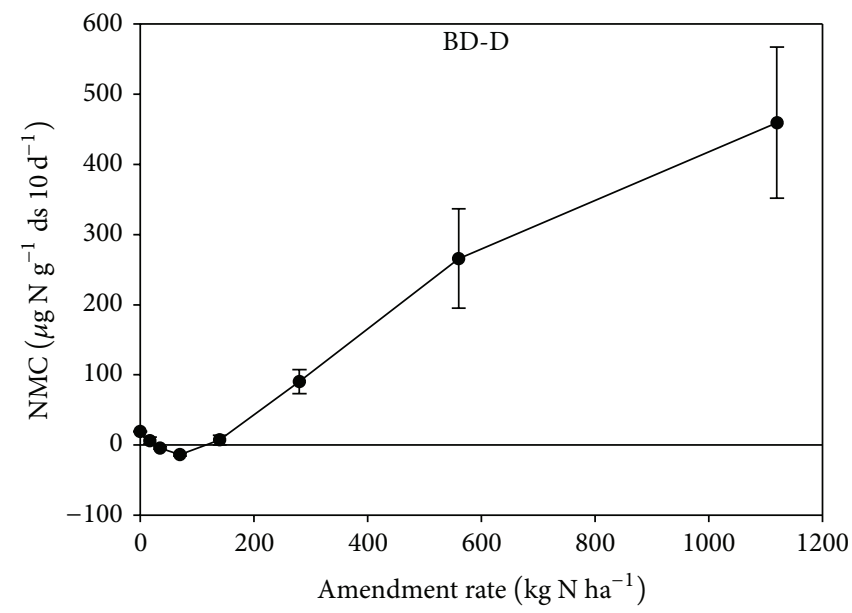

(d)

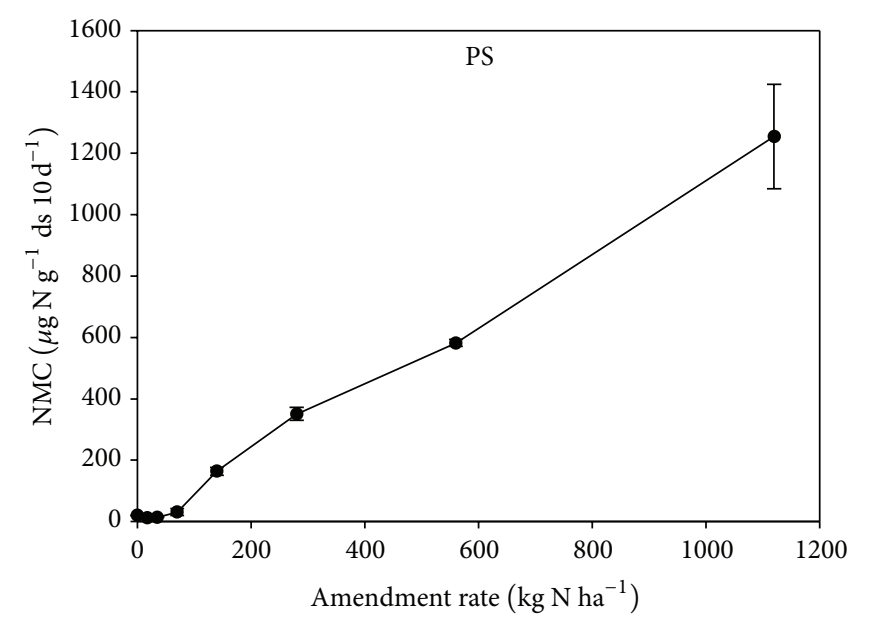

(e)

FIGURE 2: Dose-response test of nitrogen mineralization capacity (NMC) in the soil after amendment with different types of biogas residues (BD-A, BD-B, BD-C, and BD-D) and pig slurry (PS). Error bars represent mean values \pm standard deviation $(n=3)$. Note the difference in the $y$-axis scaling of PS. 


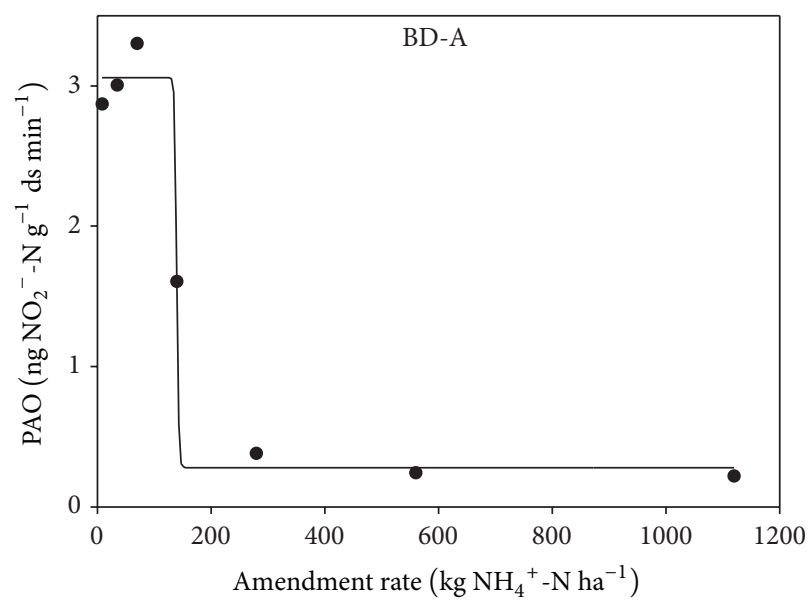

(a)

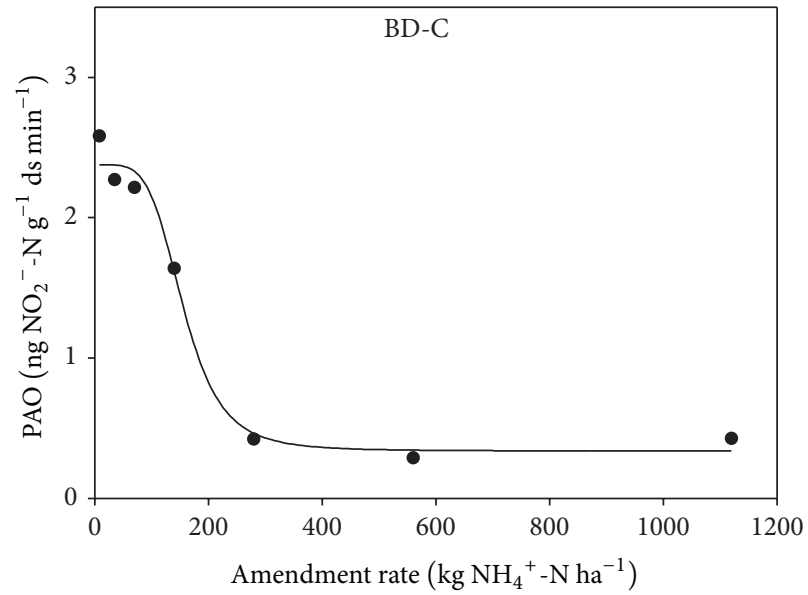

(c)

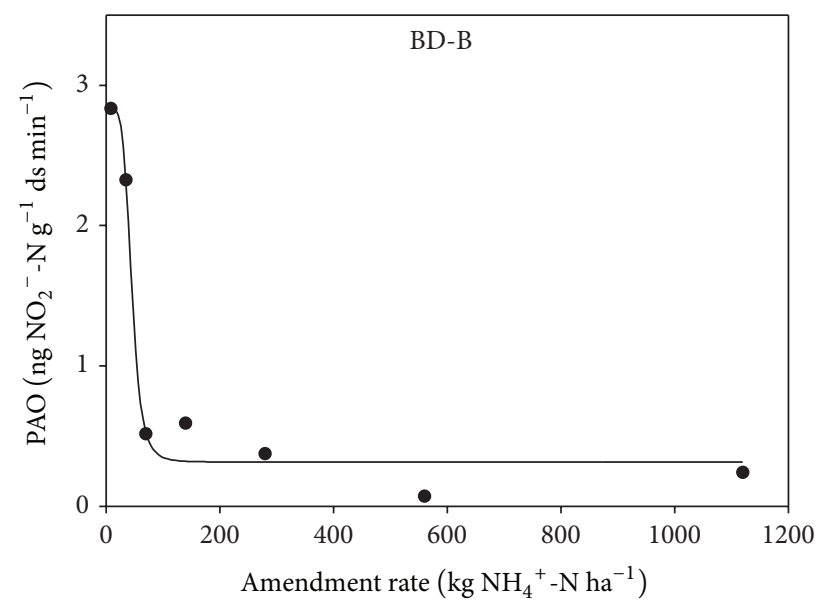

(b)

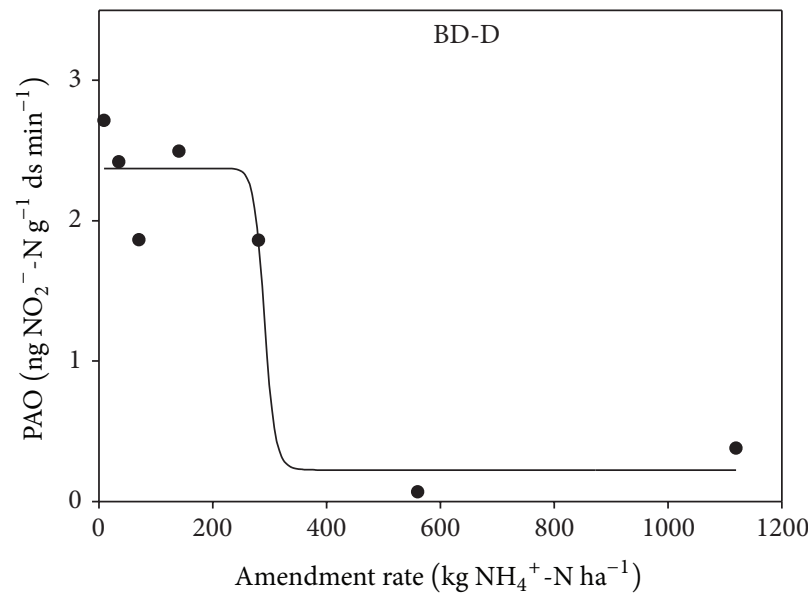

(d)

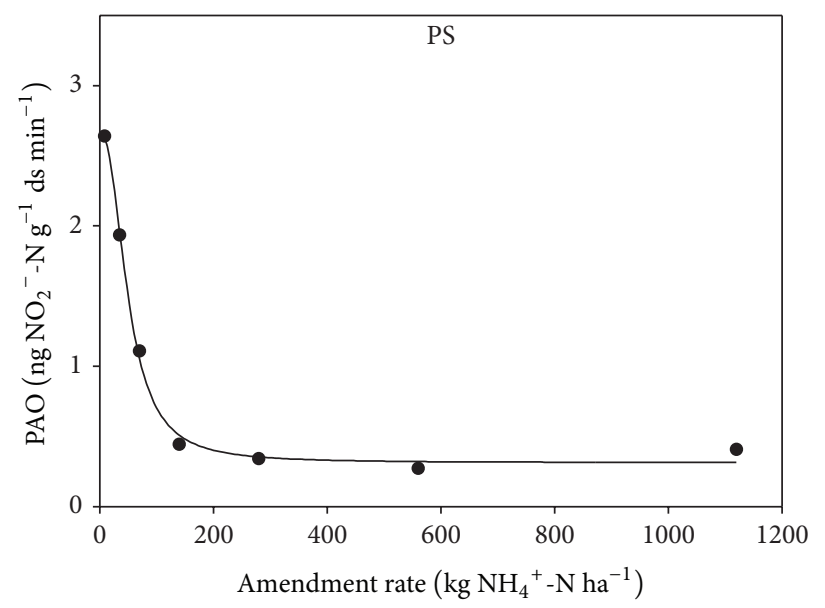

(e)

Figure 3: Potential ammonium oxidation (PAO) in the soil at seven amendment rates of four types of biogas residues (BD-A, BD-B, BD-C, and BD-D) and pig slurry (PS).

[41] observed that ca $12 \%$ and $15-33 \%$ of biogas digestate $\mathrm{C}$ were utilized, respectively. Interestingly, in the present study the utilization rate at the highest dose of BD-A and $\mathrm{BD}-\mathrm{C}$, both originating from slaughterhouse and food waste fed processes, was approximately equal to that of PS (32.5 and $30.9 \%$ versus $31.4 \%$, resp.). The low $\mathrm{C}$ utilization rate of BD-B could be explained by the fact that distiller's waste constituted $97 \%$ of the feedstock in this biogas process. Distiller's waste originates from a fermentation process optimized for converting $\mathrm{C}$ into high yields of ethanol, giving 


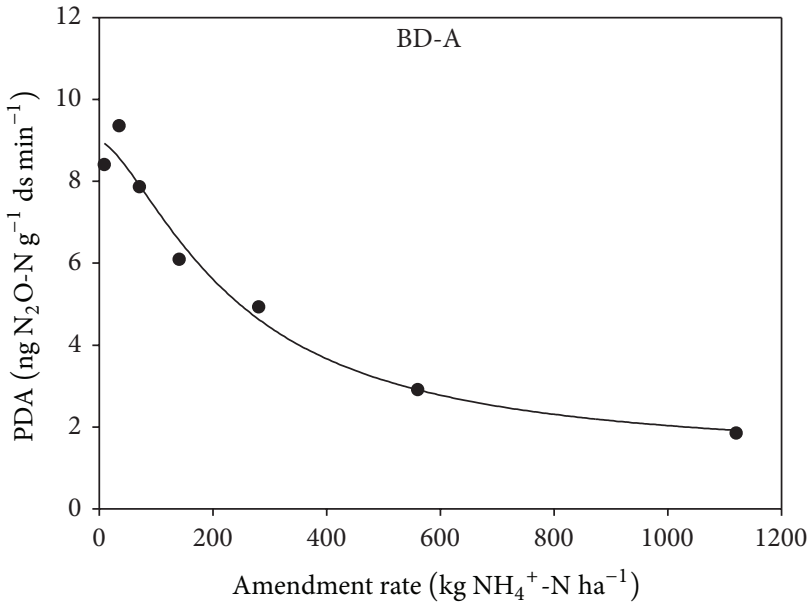

(a)

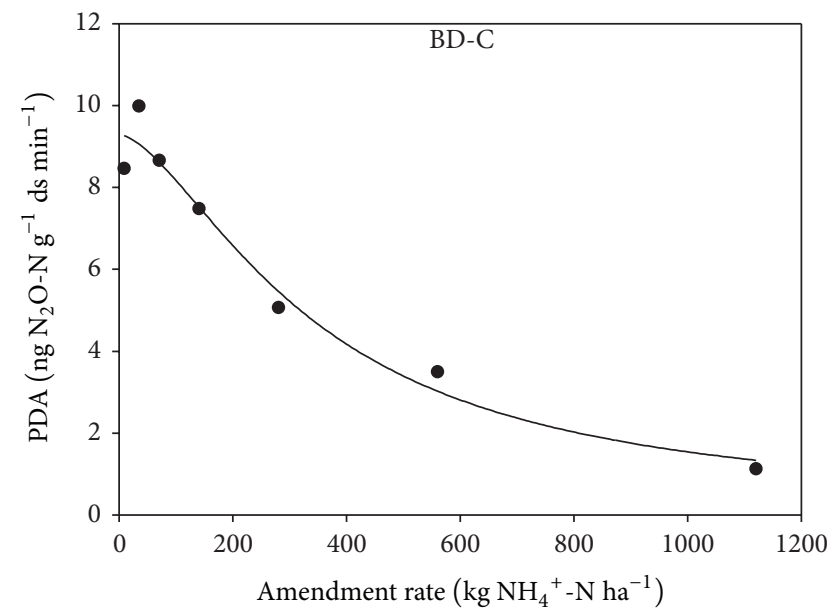

(c)

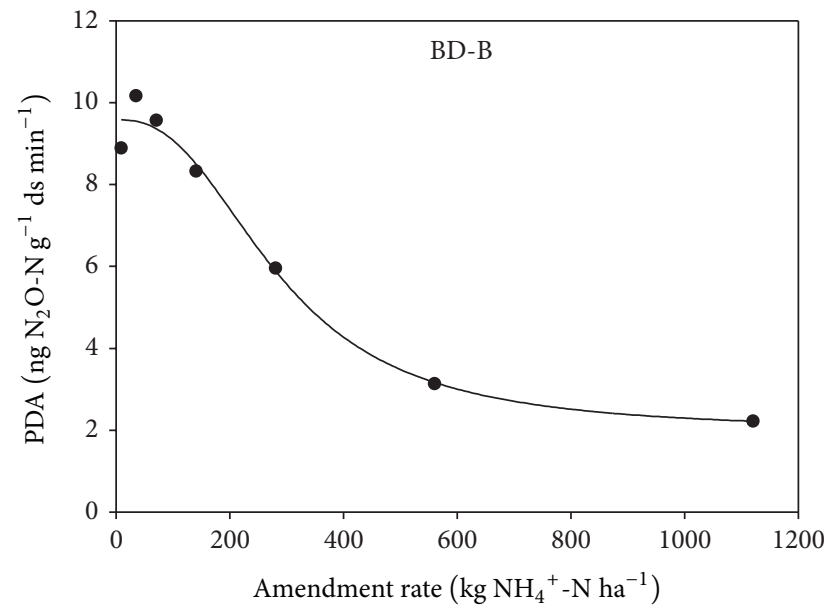

(b)

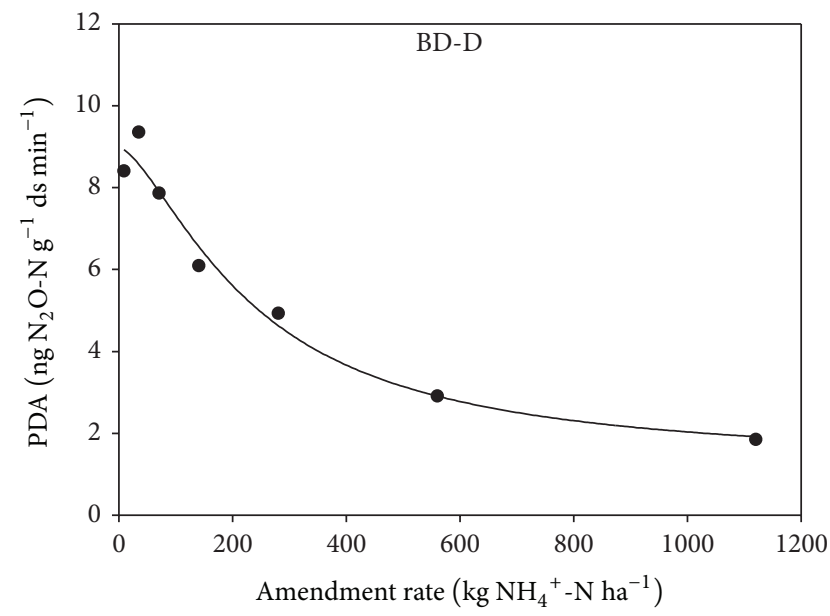

(d)

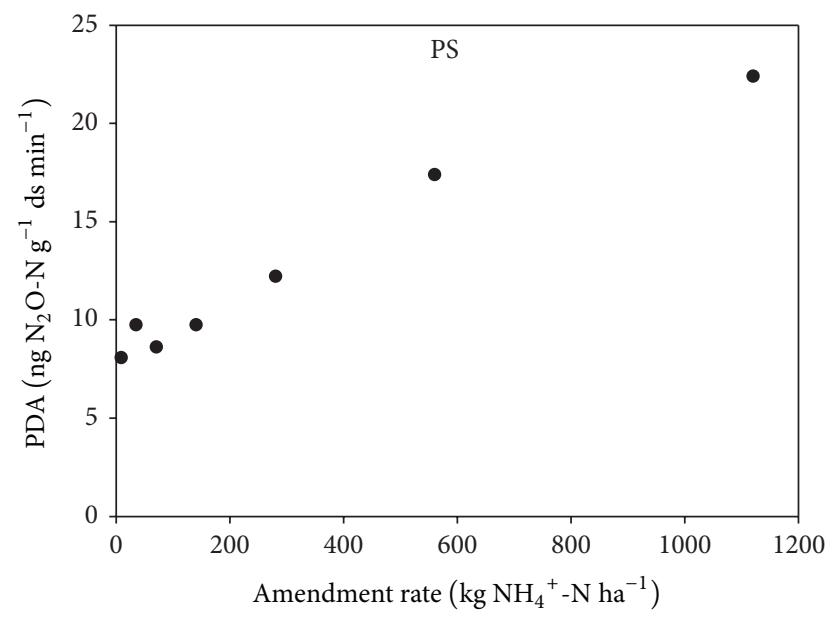

(e)

FIGURE 4: Potential denitrification activity (PDA) in the soil at seven amendment rates of four types of biogas residues (BD-A, BD-B, BD-C, and BD-D) and pig slurry (PS). 
a digestate dominated by compounds recalcitrant to further decomposition. The apparent low $\mathrm{C}$ utilization rate of $\mathrm{BD}-\mathrm{D}$ is probably an effect of the main respiration peak occurring before the first respirometer readings in the experiment.

4.2. Nitrogen Mineralization Capacity. Normally, the $\mathrm{C} / \mathrm{N}$ ratio of the degraded material regulates if nitrogen is assimilated or mineralized; when organic amendments with $\mathrm{C} / \mathrm{N}$ ratios below 20 are added to soils, net mineralization dominates, while at higher $\mathrm{C} / \mathrm{N}$ ratio net assimilation is the dominant process $[42,43]$. In the present study the $\mathrm{C} / \mathrm{N}$ ratio of the organic matter in the $\mathrm{BDs}$ ranged between 4.2 and 12 , while it was 13 in the PS; theoretically, this should have stimulated mineralization, resulting in a net release of $\mathrm{N}$. This held true for the highest doses of BDs, where it seemed that available $\mathrm{C}$ in the soil and residues was limiting and could not sustain the ability of the microorganisms to assimilate the ammonium released. The observations made in the supplementary glucose experiment confirmed that $\mathrm{C}$ limited $\mathrm{N}$ assimilation in these cases. Adding glucose to the soil amended with a high dose of $\left(\mathrm{NH}_{4}{ }^{+}\right)_{2} \mathrm{SO}_{4}$ resulted in net assimilation, while glucose addition to the soil amended with $\mathrm{BD}-\mathrm{D}$ caused a transition from net mineralization to net assimilation, and the balance was further shifted by increasing glucose concentration (data not shown), confirming observations by Azam et al. [44]. A correlation between the content of easily available $\mathrm{C}$ in the organic residue and the amounts of nitrogen immobilized was also demonstrated by, for example, Kirchmann and Lundvall [39] who concluded that fatty acids acted as an easily decomposable $\mathrm{C}$ source for microorganisms, causing assimilation of $\mathrm{N}$ upon application to soil.

At lower doses, additions of BDs induced a small but significant net assimilation rather than release of $\mathrm{N}$, indicating that the $\mathrm{C} / \mathrm{N}$ ratio of the added digestate alone did not determine which process dominated. However, this $\mathrm{N}$ assimilation is likely to be a transient process since addition of the same digestates at application rates between 35 and $140 \mathrm{~kg}$ $\mathrm{NH}_{4}{ }^{+}-\mathrm{N} \mathrm{ha}^{-1}$ was found to stimulate $\mathrm{N}$ mineralization after 77 days of incubation in a pot experiment with spring wheat [45]. An initial period of immobilization of ammonium after application of anaerobically digested material to the soil has been reported before in several studies [36, 46]. Alburquerque et al. [36] attributed this assimilation to a concomitant high microbial activity/carbon mineralization.

The $\mathrm{C} / \mathrm{N}$ ratio of the residues used in the present study could not explain the variability in $\mathrm{N}$ mineralization capacity between the amendment types; specific compounds in the BDs may therefore be more critical for short-term $\mathrm{N}$ turnover than the total contents of $\mathrm{C}$ and $\mathrm{N}$. These observations agree well with those of, for example, Qafoku et al. [47] who found that potential $\mathrm{N}$ mineralization was strongly correlated with water-soluble organic $\mathrm{N}$ but poorly correlated with the $\mathrm{C} / \mathrm{N}$ ratio. This confirms that discussing short-term $\mathrm{N}$ mineralization in terms of the available fractions of $\mathrm{C}$ and $\mathrm{N}$, rather than the total amounts, is more informative. The pattern of respiration rates following application of organic materials to the soil may indicate which compounds and amounts that are decomposed $[48,49]$. For example, the $t_{\text {peakmax }}$ of BD-A and a second hump on the respiration curve of PS, both at 70-80 h, coincided in time with respiration peaks seen after addition of sole proteins (i.e., albumin, casein, and rubisco) under similar experimental conditions by Gunnarsson and Marstorp [50] and Gunnarsson (unpublished). This could indicate that proteins contained in BD-A and PS were decomposed at this time, leading to the observed net mineralization of $\mathrm{N}$ and lending support to the notion that differences in $\mathrm{N}$ mineralizing capacity of the amendments may be sought in their easily available organic fractions.

4.3. Ammonia Oxidation and Denitrification Activity. All tested residues inhibited PAO and PDA at amendment rates that could be considered realistic field rates and sometimes even at lower rates, with the exception of PS that stimulated PDA at all rates. One possible explanation for this inhibitory effect could be pollutants contained in these residues, and, hence, the results should be considered an early warning of potential contamination. It has been shown that ammonia oxidation is sensitive to pollutants that are commonly found in PS and BDs, for example, phenols [51]. Furthermore, anaerobically digested residue contains various organic compounds such as fatty acid esters $[52,53]$, which affect ammonia oxidation negatively $[54,55]$. It has also been shown that anaerobically digested residues originating from source-separated organic waste and industrial food waste can contain high concentrations of organic pollutants such as polycyclic aromatic hydrocarbons (PAH) and diethylhexyl phthalate (DEHP), as well as high concentrations of fungicides such as imazalil and thiabendazole [56], which might affect soil microorganisms negatively. Residues generated from anaerobic digestion at thermophilic temperatures affect ammonia oxidation more negatively than mesophilic digestates [57], since the degradation of organic pollutants is more efficient under lower temperatures $[8,51]$. This could also be the explanation for the higher $\mathrm{EC}_{10}$ values observed for PAO in the present study upon addition of BD-A and BD-D compared with the other two BDs, as the former digestates originated from mesophilic processes. Moreover, at doses corresponding to between 70 and $1120 \mathrm{~kg} \mathrm{NH}_{4}{ }^{+}$ $\mathrm{Nha}^{-1}$, concentrations of $\mathrm{Cu}$ and $\mathrm{Zn}$ ranged between 1.4$50 \mathrm{mg}$ and $10-252 \mathrm{mg} \mathrm{kg}^{-1}$ of soil, respectively. The higher concentrations of $\mathrm{Cu}$ and $\mathrm{Zn}$ in these cases fell within the range that is toxic for denitrification, as Holtan-Hartwig et al. [58] observed that adding 0.32 and $120 \mathrm{mg} \mathrm{kg}^{-1}$ soil of $\mathrm{Cu}$ and $\mathrm{Zn}$, respectively, to the soil can inhibit denitrification activity. However, the inhibitory effects observed on PAO and PDA may last for just a very short period as shown by Abubaker [59] when he measured the activity $24 \mathrm{~h}, 11$, and 24 days after addition of the same biogas digestates. Such transient negative effects on ammonia oxidation bacteria have also been observed by Nyberg et al. [57] in soil amended with PS.

In contrast, no inhibition effect of PDA was detected in the soil amended with PS, instead, a stimulatory effect was observed which was positively correlated with increasing doses of PS. The higher supply of $\mathrm{C}$ with PS addition could have been a possible explanation for the higher PDA, since 
denitrifying bacteria use $\mathrm{C}$ as energy source [60]. However, doubling the amount of glucose or adding a trace element solution did not increase the PDA in comparison with the control (data not shown). Instead, the low PDA of heattreated PS indicated that the PS itself contained denitrifiers or heat-sensitive enzymes with denitrifying abilities.

\section{Conclusions}

Application of four different biogas digestates and pig slurry to soil resulted in both stimulatory and inhibitory shortterm effects on microbial functions. Soil respiration displayed varying patterns, reflecting the differences in both the quantity and quality of the organic carbon in the residues, but no negative effects were observed. Based on the nitrogen mineralization capacity results, it can be concluded that adding biogas digestates to the soil system could limit the nitrogen availability to plant roots in the short-term at rates ranging between 70 and $280 \mathrm{~kg} \mathrm{NH}_{4}^{+}-\mathrm{Nha}^{-1}$. The results also showed that fertilization with pig slurry resulted in more available mineral $\mathrm{N}$ in the soil compared with addition of biogas digestates. This is probably the explanation of the results reported about the same residues by Abubaker et al. [45], where PS gave high wheat yield compared to BDs. Adding biogas digestates to the soil had a strong negative effect on both ammonia oxidation and denitrification, which is a concern in terms of soil health and should be an early warning of potential hazardous substances in the residues. However, retarded nitrification and denitrification directly after application of a residue can also be regarded as positive, as losses of nitrogen by leaching or gaseous emissions could thereby be decreased.

\section{Conflict of Interests}

The authors declare that there is no conflict of interests regarding the publication of this paper.

\section{Acknowledgments}

The authors gratefully acknowledge the MicroDrivE program (http://microdrive.phosdev.se) funded by the Swedish University of Agricultural Sciences (SLU) for financially supporting and encouraging this work.

\section{References}

[1] P. Börjesson and B. Mattiasson, "Biogas as a resource-efficient vehicle fuel," Trends in Biotechnology, vol. 26, no. 1, pp. 7-13, 2008.

[2] S. Fouda, S. von Tucher, F. Lichti, and U. Schmidhalter, "Nitrogen availability of various biogas residues applied to ryegrass," Journal of Plant Nutrition and Soil Science, vol. 176, no. 4, pp. 572-584, 2013.

[3] A. Herrmann, K. Sieling, B. Wienforth, F. Taube, and H. Kage, "Short-term effects of biogas residue application on yield performance and $\mathrm{N}$ balance parameters of maize in different cropping systems," Journal of Agricultural Science, vol. 151, no. 4, pp. 449-462, 2013.
[4] M. Kvasauskas and P. Baltrènas, "Anaerobic recycling of organic waste and recovery of biogas," Ekologija, vol. 54, no. 1, pp. 57-63, 2008.

[5] M. H. Gerardi, The Microbiology of Anaerobic Digesters, John Wiley \& Sons, Hoboken, NJ, USA, 2003.

[6] T. Kupper, D. Bürge, H. J. Bachmann, S. Güsewell, and J. Mayer, "Heavy metals in source-separated compost and digestates," Waste Management, vol. 34, no. 5, pp. 867-874, 2014.

[7] M. Engwall and A. Schnürer, "Fate of Ah-receptor agonists in organic household waste during anaerobic degradationestimation of levels using EROD induction in organ cultures of chick embryo livers," Science of the Total Environment, vol. 297, no. 1-3, pp. 105-108, 2002.

[8] L. Levén and A. Schnürer, "Effects of temperature on biological degradation of phenols, benzoates and phthalates under methanogenic conditions," International Biodeterioration \& Biodegradation, vol. 55, no. 2, pp. 153-160, 2005.

[9] M. Pell, B. Stenberg, and L. Torstensson, "Potential denitrification and nitrification tests for evaluation of pesticide effects in soil," Ambio, vol. 27, no. 1, pp. 24-28, 1998.

[10] M. Odlare, M. Pell, and K. Svensson, "Changes in soil chemical and microbiological properties during 4 years of application of various organic residues," Waste Management, vol. 28, no. 7, pp. 1246-1253, 2008.

[11] A. K. Bandick and R. P. Dick, "Field management effects on soil enzyme activities," Soil Biology and Biochemistry, vol. 31, no. 11, pp. 1471-1479, 1999.

[12] L. A. Biederman and S. G. Whisenant, "Amendment placement directs soil carbon and nitrogen cycling in severely disturbed soils," Restoration Ecology, vol. 19, no. 3, pp. 360-370, 2011.

[13] A. Michelsen, M. Andersson, M. Jensen, A. Kjøller, and M. Gashew, "Carbon stocks, soil respiration and microbial biomass in fire-prone tropical grassland, woodland and forest ecosystems," Soil Biology and Biochemistry, vol. 36, no. 11, pp. 1707-1717, 2004.

[14] R. C. Dalal, "Soil microbial biomass-what do the numbers really mean?" Australian Journal of Experimental Agriculture, vol. 38, no. 7, pp. 649-665, 1998.

[15] R. Nieder, E. Neugebauer, A. Willenbockel, K. C. Kersebaum, and J. Richter, "Nitrogen transformation in arable soils of North-West Germany during the cereal growing season," Biology and Fertility of Soils, vol. 22, no. 1-2, pp. 179-183, 1996.

[16] T. Rosswall, "Microbiological regulation of the biogeochemical nitrogen cycle," Plant and Soil, vol. 67, no. 1-3, pp. 15-34, 1982.

[17] M. Odlare and M. Pell, "Effect of wood fly ash and compost on nitrification and denitrification in agricultural soil," Applied Energy, vol. 86, no. 1, pp. 74-80, 2009.

[18] A. N. Harvey, I. Snape, and S. D. Siciliano, "Validating potential toxicity assays to assess petroleum hydrocarbon toxicity in polar soil," Environmental Toxicology and Chemistry, vol. 31, no. 2, pp. 402-407, 2012.

[19] P. van Beelen and P. Doelman, "Significance and application of microbial toxicity tests in assessing ecotoxicological risks of contaminants in soil and sediment," Chemosphere, vol. 34, no. 3, pp. 455-499, 1997.

[20] B. Stenberg, M. Johansson, M. Pell, K. Sjödahl-Svensson, J. Stenström, and L. Torstensson, "Microbial biomass and activities in soil as affected by frozen and cold storage," Soil Biology \& Biochemistry, vol. 30, no. 3, pp. 393-402, 1998.

[21] H. Egnér, H. Riehm, and W. R. Domingo, "Investigations on chemical soil analysis as the basis for estimating soil fertility, 
II. Chemical extraction methods for phosphorus and potassium determination," Kunliga Lantbruksögskolans Annaler, vol. 26, pp. 199-215, 1960.

[22] Swedish Institute for Standards (SIS), "Soil analysisdetermination of trace elements in soil-extraction with nitric acids," Tech. Rep. SS028311, Swedish Institute for Standards (SIS), Stockholm, Sweden, 1997.

[23] R. G. McLaren and K. C. Cameron, Soil Science: Sustainable Production and Environmental Protection, 2nd Ed, Oxford University Press, Oxford, UK, 1996.

[24] G. Jung, "Mekanisk analys_-beskrivning av en rationell metod för jordartsbestämning (mechanical analysis-a description of a rational method for determination of soil type)," Report 87:2, Department of Soil Science, The Swedish University for Agricultural Sciences, 1987.

[25] SIS (Swedish Standards Institute), "Characterization of sludges: determination of dry residue and water content," Tech. Rep. SSEN Standard 12880, SIS (Swedish Standards Institute), Stockholm, Sweden, 2000, (Swedish).

[26] International Organization for Standardization, "Soil qualitydetermination of organic and total carbon after dry combustion (elementar analysis)," ISO 10694, ISO, Geneva, Switzerland, 1995.

[27] ISO (International Organization for Standardization), "Soil quality-determination of total nitrogen content by dry combustion (elemental analysis)," ISO 13878, ISO, Geneva, Switzerland, 1998.

[28] SIS (Swedish Standards Institute), Soil AnalysisDeteremination of Trace Elements in Soils-Extraction with Nitric Acids, SS28311, Stockholm, Sweden, 1997 (Swedish).

[29] A. Nordgren, "Apparatus for the continuous, long-term monitoring of soil respiration rate in large numbers of samples," Soil Biology \& Biochemistry, vol. 20, no. 6, pp. 955-957, 1988.

[30] ISO (International Organization for Standardization), "Soil quality-determination of abundance and activity of soil microflora using respiration curves," ISO 17155, ISO, Geneva, Switzerland, 2001.

[31] S. A. Waring and J. M. Bremner, "Ammonium production in soil under waterlogged conditions as an index of nitrogen availability," Nature, vol. 201, pp. 951-952, 1964.

[32] International Organization for Standardization, "Soil qualitydetermination of potential nitrification-rapid test by ammonium oxidation," ISO 15685, ISO, Geneva, Switzerland, 2004.

[33] M. Pell, B. Stenberg, J. Stenström, and L. Torstensson, "Potential denitrification activity assay in soil-with or without chloramphenicol?" Soil Biology and Biochemistry, vol. 28, no. 3, pp. 393398, 1996.

[34] J. Stenström, A. Hansen, and B. Svensson, "Kinetics of microbial growth associated product formation," Swedish Journal of Agricultural Research, vol. 21, no. 2, pp. 55-62, 1991.

[35] G. Cohen-Bazire, W. R. Sistrom, and R. Y. Stanier, "Kinetic studies of pigment synthesis by non-sulfur purple bacteria," Journal of Cellular and Comparative Physiology, vol. 49, no. 1, pp. 25-68, 1957.

[36] J. A. Alburquerque, C. de la Fuente, and M. P. Bernal, "Chemical properties of anaerobic digestates affecting $\mathrm{C}$ and $\mathrm{N}$ dynamics in amended soils," Agriculture, Ecosystems \& Environment, vol. 160, pp. 15-22, 2012.

[37] H. Marstorp, "Influence of soluble carbohydrates, free amino acids, and protein content on the decomposition of Lolium multiflorum shoots," Biology and Fertility of Soils, vol. 21, no. 4, pp. 257-263, 1996.
[38] C. Gallert and J. Winter, "Mesophilic and thermophilic anaerobic digestion of source-sorted organic wastes: effect of ammonia on glucose degradation and methane production," Applied Microbiology and Biotechnology, vol. 48, no. 3, pp. 405-410, 1997.

[39] H. Kirchmann and A. Lundvall, "Relationship between N immobilization and volatile fatty acids in soil after application of pig and cattle slurry," Biology and Fertility of Soils, vol. 15, no. 3, pp. 161-164, 1993.

[40] S. De Neve, S. Sleutel, and G. Hofman, "Carbon mineralization from composts and food industry wastes added to soil," Nutrient Cycling in Agroecosystems, vol. 67, no. 1, pp. 13-20, 2003.

[41] C. de la Fuente, J. A. Alburquerque, R. Clemente, and M. P. Bernal, "Soil $\mathrm{C}$ and $\mathrm{N}$ mineralisation and agricultural value of the products of an anaerobic digestion system," Biology and Fertility of Soils, vol. 49, no. 3, pp. 313-322, 2013.

[42] D. D. Myrold, "Transformations of nitrogen," in Principles and Applications of Soil Microbiology, D. M. Sylvia, J. J. Fuhrmann, P. G. Hartel, and D. A. Zuberer, Eds., chapter 12, pp. 259-294, Prentice Hall, Upper Saddle River, NJ, USA, 1st edition, 999.

[43] M. S. Luce, J. K. Whalen, N. Ziadi, and B. J. Zebarth, "Nitrogen dynamics and indices to predict soil nitrogen supply in humid temperate soils," Advances in Agronomy, vol. 112, pp. 55-102, 2011.

[44] F. Azam, F. W. Simmons, and R. L. Mulvaney, "Immobilization of ammonium and nitrate and their interaction with native $\mathrm{N}$ in three Illinois Mollisols," Biology and Fertility of Soils, vol. 15, no. 1, pp. 50-54, 1993.

[45] J. Abubaker, K. Risberg, and M. Pell, "Biogas residues as fertilisers-effects on wheat growth and soil microbial activities," Applied Energy, vol. 99, pp. 126-134, 2012.

[46] M. Grigatti, G. Di Girolamo, R. Chincarini, C. Ciavatta, and L. Barbanti, "Potential nitrogen mineralization, plant utilization efficiency and soil $\mathrm{CO}_{2}$ emissions following the addition of anaerobic digested slurries," Biomass and Bioenergy, vol. 35, no. 11, pp. 4619-4629, 2011.

[47] O. S. Qafoku, M. L. Cabrera, W. R. Windham, and N. S. Hill, "Rapid methods to determine potentially mineralizable nitrogen in broiler litter," Journal of Environmental Quality, vol. 30, no. 1, pp. 217-221, 2001.

[48] S. Gunnarsson, Optimisation of N Release-Influence Of Plant Material Chemical Composition on $C$ and $N$ Mineralisation [Doctoral Thesis], vol. 381 of Acta Universitatis agriculturae Suecia, Swedish University of Agricultural Sciences, 2003.

[49] S. Gunnarsson, H. Marstorp, A. S. Dahlin, and E. Witter, "Influence of non-cellulose structural carbohydrate composition on plant material decomposition in soil," Biology and Fertility of Soils, vol. 45, no. 1, pp. 27-36, 2008.

[50] S. Gunnarsson and H. Marstorp, "Carbohydrate composition of plant materials determines $\mathrm{N}$ mineralisation," Nutrient Cycling in Agroecosystems, vol. 62, no. 2, pp. 175-183, 2002.

[51] L. Levén, K. Nyberg, L. Korkea-aho, and A. Schnürer, "Phenols in anaerobic digestion processes and inhibition of ammonia oxidising bacteria (AOB) in soil," Science of the Total Environment, vol. 364, no. 1-3, pp. 229-238, 2006.

[52] M.-L. Nilsson, H. Kylin, and P. Sundin, "Major extractable organic compounds in the biologically degradable fraction of fresh, composted and anaerobically digested household waste," Acta Agriculturae Scandinavica Section B: Soil and Plant Science, vol. 50, no. 2, pp. 57-65, 2000.

[53] R. R. Singhania, A. K. Patel, G. Christophe, P. Fontanille, and C. Larroche, "Biological upgrading of volatile fatty acids, key 
intermediates for the valorization of biowaste through dark anaerobic fermentation," Bioresource Technology, vol. 145, pp. 166-174, 2013.

[54] M. R. Hockenbury and C. P. L. Grady Jr., "Inhibition of nitrification: effects of selected organic compounds," Journal of the Water Pollution Control Federation, vol. 49, no. 5, pp. 768777, 1977.

[55] G. V. Subbarao, K. L. Sahrawat, K. Nakahara et al., "A paradigm shift towards low-nitrifying production systems: the role of biological nitrification inhibition (BNI)," Annals of Botany, vol. 112, no. 2, pp. 297-316, 2013.

[56] E. Govasmark, J. Stäb, B. Holen, D. Hoornstra, T. Nesbakk, and M. Salkinoja-Salonen, "Chemical and microbiological hazards associated with recycling of anaerobic digested residue intended for agricultural use," Waste Management, vol. 31, no. 12, pp. 2577-2583, 2011.

[57] K. Nyberg, A. Schnürer, I. Sundh, Å. Jarvis, and S. Hallin, "Ammonia-oxidizing communities in agricultural soil incubated with organic waste residues," Biology and Fertility of Soils, vol. 42, no. 4, pp. 315-323, 2006.

[58] L. Holtan-Hartwig, M. Bechmann, T. R. Høyås, R. Linjordet, and L. R. Bakken, "Heavy metals tolerance of soil denitrifying communities: $\mathrm{N}_{2} \mathrm{O}$ dynamics," Soil Biology and Biochemistry, vol. 34, no. 8, pp. 1181-1190, 2002.

[59] J. Abubaker, Effects of fertilisation with biogas residues on crop yield, soil microbiology and greenhouse gas emissions [Ph.D. thesis], Acta Universitatis Agriculturae Suecia, 2012.

[60] L. Philippot, S. Hallin, and M. Schloter, "Ecology of denitrifying prokaryotes in agricultural soil," Advances in Agronomy, vol. 96, pp. 249-305, 2007. 

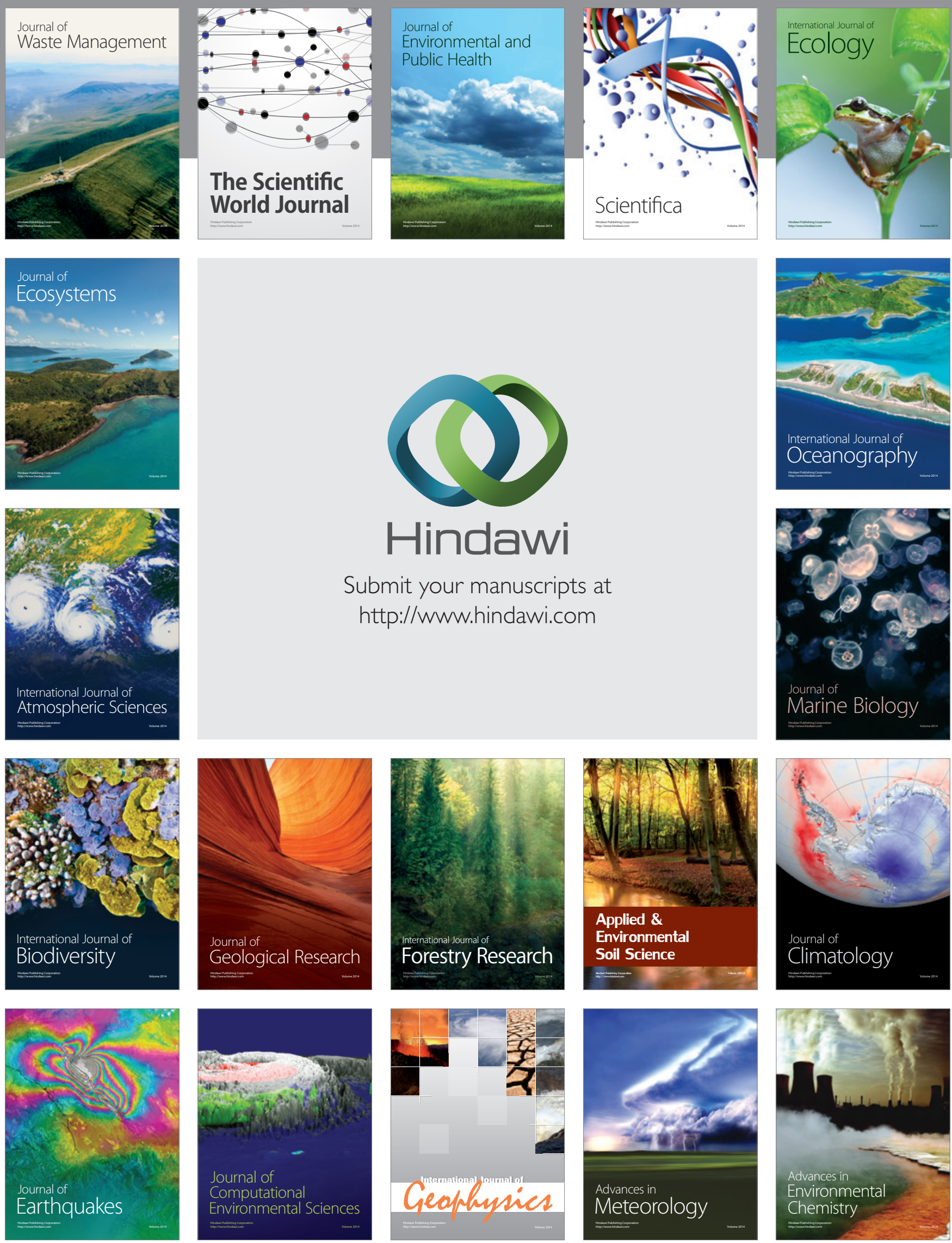